\title{
Lenition and Phonemic Overlap in Rome Italian
}

\author{
José Ignacio Hualde Marianna Nadeu \\ University of Illinois at Urbana-Champaign, Urbana, III., USA
}

\begin{abstract}
The purpose of this paper is to offer acoustic evidence for an unusual phonemic contrast in Rome Italian. In our corpus, about half of all tokens of intervocalic $/ \mathrm{p} \mathrm{t} \mathrm{k/} \mathrm{are} \mathrm{realized} \mathrm{with} \mathrm{uninterrupted} \mathrm{voicing} \mathrm{(both} \mathrm{word-internally} \mathrm{and} \mathrm{across}$ word boundaries). Furthermore, the voiced realizations of $/ \mathrm{t} /$ and $/ \mathrm{k} /$ do not significantly differ from $/ \mathrm{d} /$ and $/ \mathrm{g} /$ in duration and/or degree of constriction (as acoustically determined). Phonemic contrast is maintained under substantial phonetic overlap. Regarding the labials, duration keeps $/ \mathrm{p} /$ and $/ \mathrm{b} /$ apart. Contrary to the universal tendency, it is $/ \mathrm{b} /$ that is considerably longer, due to complex diachronic facts.
\end{abstract}

Copyright (c) 2012 S. Karger AG, Basel

\section{Introduction}

In a classical view, phonemes are categorically distinct, essentially nonoverlapping entities, although their overlap in specific environments may lead to contextual neutralization. This view has been challenged by the phenomena of 'incomplete neutralization' [Port and O'Dell, 1985; Port and Crawford, 1989] and 'near-merger' [Labov, 1994], as well as by the existence of 'quasi-phonemic contrasts' [Hualde, 2004; Scobbie and Stuart-Smith, 2008].

Hualde et al. [2011] examine the realization of intervocalic stops in Iberian Spanish, a language where acoustic study has revealed frequent voicing of intervocalic consonants [Torreblanca, 1976; Machuca Ayuso, 1997; Lewis, 2001; Martínez Celdrán, 2009]. They show that, even though the phonemes $/ \mathrm{p} \mathrm{t} \mathrm{k/} \mathrm{are} \mathrm{realized} \mathrm{as} \mathrm{(fully} \mathrm{or} \mathrm{par-}$ tially) voiced, approximately in a third of all tokens in their corpus of semidirected unscripted speech, there is very little actual overlap with /b d g/. The two series are significantly different both in duration and in degree of constriction as determined from the acoustic signal, $/ \mathrm{p} \mathrm{t} \mathrm{k} /$ being longer and more constricted than $/ \mathrm{b} \mathrm{d} \mathrm{g} /$ even when realized as fully voiced (i.e. with uninterrupted vocal fold vibration during their constriction). The voiced realizations of $/ \mathrm{p} \mathrm{t} \mathrm{k/} \mathrm{include} \mathrm{tokens} \mathrm{that} \mathrm{could} \mathrm{be} \mathrm{classified} \mathrm{as} \mathrm{voiced} \mathrm{stops}$ and as voiced approximants, e.g. el ámbito de la politica [e'lambiðoðelabo'litiya] 'the field of politics', but overall they are more constricted than the realizations of $/ \mathrm{b} \mathrm{d} \mathrm{g/} \mathrm{in}$ the same context. The smallest difference was found for the velars, $/ \mathrm{k} / \mathrm{and} / \mathrm{g} /$.

\begin{tabular}{ll}
\hline KARGER & (c) 2012 S. Karger AG, Basel \\
& $0031-8388 / 11 / 0684-0215$ \\
Fax +41 61 306 1234 & $\$ 38.00 / 0$ \\
E-Mail karger@karger.ch & Accessible online at: \\
www.karger.com & www.karger.com/pho
\end{tabular}

J.I. Hualde

Department of Spanish, Italian and Portuguese

University of Illinois

4080 FLB, 707 South Mathews Avenue

Urbana, IL 61801 (USA)

Tel. +1 217333 3390, E-Mail jihualde@illinois.edu 
Here we examine this same contrast in Rome Italian, a language variety where the phonemes $/ \mathrm{p} \mathrm{t} \mathrm{k}$ / appear to show a greater degree of voicing and weakening than in Spanish, to such an extent that oppositions such as $/ \mathrm{t} /-\mathrm{d} / \mathrm{have}$ been claimed to be sometimes suspended in intervocalic position [Bernhard, 1998, p. 92]. The question that we want to address is how much phonetic overlap is actually found between these two contrasting series of phonemes in the context of lenition. By lenition we understand the systematic or conventionalized weakening of consonants in a given position. In the case of intervocalic voiceless plosives, their lenition may involve a shorter duration, incomplete occlusion and/or voicing. We conduct an acoustic study. The correlates that we consider are voicing (vocal fold vibration), duration and degree of constriction, as determined from sound waves and spectrograms.

From a comparative Romance point of view, it should be noted that the statement in the paragraph above regarding weakening of voiceless consonants in Spanish and Rome Italian does not refer to the same historical sounds in the two languages. Word-internal intervocalic Latin / $\mathrm{p} \mathrm{t} \mathrm{k/} \mathrm{systematically} \mathrm{became} \mathrm{/b} \mathrm{d} \mathrm{g/} \mathrm{in} \mathrm{Western} \mathrm{Romance,} \mathrm{e.g.} \mathrm{LUPU}$ $>$ Sp. lobo 'wolf', LATU > Sp. lado 'side', AMĪCU > Sp. amigo 'friend' (cf. It. lupo, lato, amico). In native words, intervocalic /p t k/ in Spanish (and other Western Romance languages) derive for the most part from Latin geminates, which were simplified but not voiced, e.g. CUPPA > Sp. copa 'cup', GUTTA > Sp. gota 'drop', SICCU > Sp. seco 'dry' (cf. It. coppa, gotta, secco). What we seem to be witnessing now in some Spanish varieties is a 'second round of voicing' affecting consonants that remained voiceless after the first round accomplished by the Western Romance voicing of intervocalic consonants [Oftedal, 1985]. The present-day lenition of $/ \mathrm{p} \mathrm{t} \mathrm{k/} \mathrm{in} \mathrm{Rome} \mathrm{Italian,} \mathrm{on} \mathrm{the} \mathrm{other} \mathrm{hand,}$ represents a 'first round of voicing' with respect to the Latin consonantal system.

Although the categorical and regular voicing of intervocalic singleton plosives and the simplification of geminates are sound changes that only affected the Western Romance area (the isogloss, known as the La Spezia/Rimini line, runs across the northern part of the Italian peninsula), it has been noted that intervocalic phonological $/ \mathrm{p} \mathrm{t}$ $\mathrm{k}$ / (in words like lupo, lato, amico) are often realized with some degree of voicing in many central and southern areas of Italy, including Rome [Rohlfs, 1966-1969, vol. 1, pp. 280-281; Bernhard, 1998; Bertinetto and Loporcaro, 2005; Marotta, 2005; among others]. This allophonic voicing process appears to be gaining ground in Rome Italian [Loporcaro, 2009; see also D'Achille and Stefinlongo, 2008]. Our goal is to contribute to the characterization of this phenomenon in Rome Italian, based on the acoustic analysis of free speech.

Italian has a four-way contrast in intervocalic plosives, involving voicing and

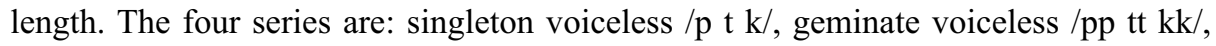
singleton voiced $/ \mathrm{b} \mathrm{d} \mathrm{g/,} \mathrm{and} \mathrm{geminate} \mathrm{voiced} / \mathrm{bb} \mathrm{dd} \mathrm{gg/.} \mathrm{Nevertheless,} \mathrm{it} \mathrm{has} \mathrm{been}$ claimed that a feature of Rome Italian is that the contrast between intervocalic $/ \mathrm{b} /$ and /bb/ has been neutralized, in favor of the geminate [Bertinetto and Loporcaro, 2005; Marotta, 2005].

At the lexical level, geminates are found only in word-internal position, after a vowel and before another vowel, glide or liquid, but word-initial consonants are also geminated in certain specific contexts. The phenomenon of word-initial gemination is known as raddoppiamento (morfo) sintattico or (morpho-)syntactic doubling (RS). RS of word-initial consonants takes place after all words ending in a stressed vowel (e.g. città [pp]iccola 'small city') and also after some specific functional words that are unstressed or do not have final stress, as long as there is no intervening pause or break 
(e.g. $a$ [kk]asa 'home', come [tt]e 'like you') [Loporcaro, 1997, pp. 1-2; Absalom et al., 2002; Borrelli, 2002, pp. 25-28].

The focus of this paper is on the contrast between singleton $/ \mathrm{p} \mathrm{t} \mathrm{k/} \mathrm{and} / \mathrm{b} \mathrm{d} \mathrm{g/,} \mathrm{but}$ we also include the geminate plosives in our analysis of duration, as it seems relevant in order to establish the phonological function of this acoustic dimension. That is, it appears to us that the consideration of duration as a possible correlate of the voiced/ voiceless contrast requires examining also the phonological function of this feature in the singleton/geminate opposition.

As we have already mentioned, the realization of singleton intervocalic plosives in Rome Italian has been characterized in terms of two processes. Voiceless intervocalic stops are said to be commonly realized as (partially or fully) voiced lenis stops. On the other hand, /b/ is realized as a geminate when intervocalic [Bernhard, 1998; Bertinetto and Loporcaro, 2005; Marotta, 2005; among others]. Two opposite tendencies have thus been identified: voicing and weakening of voiceless stops [and fricatives, Nocchi and Schmid, 2007] and fortition of labial voiced stops. Neither phenomenon, the lenition of $/ \mathrm{p} \mathrm{t} \mathrm{k}$ / or the strengthening of $/ \mathrm{b} /$, appears to carry either overt sociolinguistic prestige or stigma in the awareness of speakers of Rome Italian [Stefinlongo, 1985, pp. 53-54], although speakers seem to be aware that lenition may create homophony [Bernhard, 1998, p. 92]. Compared to lenition in Tuscan Italian, where voiceless stops tend to be realized as voiceless fricatives [Giannelli and Savoia, 1978, 1979-1980; Cravens, 1984; Marotta, 2001, 2008; Sorianello, 2001; Villafaña Dalcher, 2006], the voicing lenition found in Rome and in other central and southern varieties of Italian would seem to more directly threaten the opposition between voiced and voiceless plosives.

To anticipate the results of our acoustic analysis, we find that, for the coronals and velars the range of the phonologically voiced phonemes appears to fall within the range of their phonologically voiceless counterparts. The results indicate that intervocalically there is substantial overlap between lenited $/ \mathrm{t} /$ and $/ \mathrm{d} /$ and between $/ \mathrm{k} /$ and $/ \mathrm{g} /$, although $/ \mathrm{t} /$ and $/ \mathrm{k} /$ also admit stronger, nonlenited, realizations in this context. This is a situation that, in principle, should favor the transfer between phonemic categories in individual lexical items. The question that arises is what prevents the phonological contrast from completely collapsing, at least in the intervocalic context. The gemination of intervocalic $/ \mathrm{b} /$ prevents neutralization in the labials.

Even though our focus in this paper is primarily synchronic, the results may also be useful in our understanding of diachronic processes and we offer some discussion at the end of the paper. In this respect an important fact to keep in mind, and to which we will return in the discussion, is that whereas the Western Romance sound change $/ \mathrm{p} \mathrm{t} \mathrm{k} />/ \mathrm{b} \mathrm{d} \mathrm{g} /$ between vowels only affected word-medial consonants (e.g. Lat. ILLA PORTA is still Sp. la puerta 'the door', Fr. la porte), the synchronic allophonic lenition of intervocalic $/ \mathrm{p} \mathrm{t} \mathrm{k} /$ in Rome Italian affects both word-medial and word-initial consonants [e.g. Bertinetto and Loporcaro, 2005], as does the more incipient 'second round of voicing' found in Spanish [Hualde et al., 2011].

\section{Methods}

We have analyzed semispontaneous directed conversation data from 6 speakers of Rome Italian. The data are from recordings collected for the project Corpora e Lessici dell'Italiano Parlato e Scritto (CLIPS), directed by Federico Albano Leoni and available online for download by registered users. 
This corpus is organized by town and contains both high-quality recordings and their orthographic transcriptions. We have limited our scope to conversational speech (dialog) of the Rome part of the corpus. We have analyzed data from three 'map tasks' and three other dialogs from a cooperative game known as 'find the differences' (for details see http://www.clips.unina.it/it/documenti/2_tecniche_di elicitazione_dialogica.pdf.). Marotta [2005] analyzes a small sample (about 15 min of a single conversation between 2 speakers) from the same corpus and offers an overview of consonantal processes.

The acoustic analysis has been carried out with PRAAT [Boersma, 2001]. In the sound waves we have identified and segmented all instances of phonological intervocalic voiced and voiceless plosives, both singleton and geminate, occurring both word-internally and across word boundaries without an intervening pause or break. We include tokens where the consonant was followed by a liquid or glide, since voicing of $/ \mathrm{p} \mathrm{t} \mathrm{k}$ / was also observed in these contexts. That is, we are using the label 'intervocalic' for a context that is more properly defined as 'postvocalic syllable-initial' [see, e.g. Gianelli and Cravens, 1997]. In this we follow tradition. (Notice that Western Romance 'intervocalic' voicing also applies in, e.g. PETRA > Sp. piedra 'stone', AQUA > Sp. agua 'water'.)

For the segmentation of stop realizations, we have placed a mark indicating the beginning of the consonant when the waveform revealed a decrease in amplitude and formant energy in the spectrogram ceased. In order to verify the location of voiced approximants, which have less clear boundaries than other consonants, we used the intensity curve displayed by PRAAT, which typically revealed a slight dip. Although formant structure might still be present, spectrograms of approximants show lighter shades at all frequencies than flanking vowels. An increase in amplitude in the waveform was taken as the beginning of the vowel and, hence, the end of the consonant.

Since we are interested in the possible neutralization of weakened realizations of $/ \mathrm{p} \mathrm{t} \mathrm{k} /$ with phonemic $/ \mathrm{b} \mathrm{d} \mathrm{g} /$, we have labeled tokens of $/ \mathrm{p} \mathrm{t} \mathrm{k/} \mathrm{with} \mathrm{uninterrupted} \mathrm{voicing} \mathrm{separately} \mathrm{from} \mathrm{other} \mathrm{tokens.}$ Our reasoning is that tokens of $/ \mathrm{p} \mathrm{t} \mathrm{k/} \mathrm{showing} \mathrm{uninterrupted} \mathrm{voicing} \mathrm{are} \mathrm{more} \mathrm{likely} \mathrm{to} \mathrm{show} \mathrm{complete}$ neutralization with underlying or phonemic $/ \mathrm{b} \mathrm{d} \mathrm{g/.} \mathrm{In} \mathrm{the} \mathrm{case} \mathrm{of} \mathrm{phonological} / \mathrm{p} \mathrm{t} \mathrm{k/,} \mathrm{then,} \mathrm{different}$ labels have been used for voiceless and voiced realizations. A token has been classified as 'voiced' only if there was continuous voicing during the consonantal constriction, as evidenced by the presence of pulses throughout the segment and lack of interruption in the F0 display in PRAAT. All other tokens, including those with partial voicing, have been classified as 'voiceless'. The reason is that if voicing is incomplete, that may be enough to keep the two phonological series apart. Again, something we want to know is whether fully voiced allophones of $/ \mathrm{p} \mathrm{t} \mathrm{k/} \mathrm{differ} \mathrm{in} \mathrm{other} \mathrm{properties} \mathrm{from} / \mathrm{b} \mathrm{d} \mathrm{g} /$ in the same position. We are thus being conservative in our use of the label 'voiced'. Our strict use of the label 'voiced' also allows for a more straightforward classification of tokens as belonging to one category or the other.

The phonetic voicing of phonologically voiceless consonants does not necessarily imply their neutralization with their phonologically voiced counterparts. The phonemic contrast could be maintained by differences in duration and/or degree of constriction. For this reason, beyond classifying tokens as phonetically 'voiceless' (including partially voiced) or fully 'voiced', we took measurements of consonant duration (excluding the release portion or positive voice onset time) and of constriction, as reflected in the acoustics. Voice onset time has been excluded because it could not be determined for a majority of our voiced singleton tokens, which are realized without release.

To determine the degree of constriction we employed two measurements taken from the intensity curve in PRAAT, which we call Intensity Difference (IntDiff) and Maximum Rising Velocity (MaxVel). These two measures of constriction have been previously tested in the analysis of the $/ \mathrm{b} /-/ \mathrm{v} /$ contrast in Majorcan Catalan [Hualde et al., 2010] and of the contrast between the two series of plosives in Spanish [Hualde et al., 2011]. IntDiff is the difference between the maximum intensity during the following tautosyllabic vowel and the minimum intensity during the production of the consonant. The greater the consonant constriction, the greater this difference is predicted to be. A number of studies have used relative intensity as a measurement of degree of constriction [see Soler and Romero, 1999; Cole et al., 1999; Lavoie, 2001; Ortega-Llebaria, 2004; Villafaña Dalcher, 2006]. When the target consonant was immediately followed by a liquid or a glide, the maximum intensity value would normally be found during the following vowel. That is, for instance, to calculate IntDiff for the wordinitial / $\mathrm{p} /$ of $i$ piedi 'the feet', we take the minimum intensity within $/ \mathrm{p} /$ and the maximum intensity within the same syllable, which is found in /e/ in this case.

MaxVel is a measurement of the abruptness of the transition between the target consonant and the following vowel, reducing possible effects of variation in the intensity of the vowel. This measure is based, with some modifications, on Kingston [2008]. MaxVel is calculated as the maximum value 
Table 1. Number of word-initial and word-medial tokens (intervocalic consonants)

\begin{tabular}{lrrr}
\hline Consonant & Word-initial & Word-medial & Total \\
\hline /p/ & 283 & 165 & 448 \\
$/ \mathrm{t} /$ & 106 & 135 & 241 \\
$/ \mathrm{k} /$ & 328 & 67 & 395 \\
$/ \mathrm{b} /$ & 46 & 12 & 58 \\
$/ \mathrm{d} /$ & 356 & 105 & 461 \\
$/ \mathrm{g} /$ & 24 & 42 & 66 \\
$/ \mathrm{pp} /$ & 13 & 103 \\
$/ \mathrm{tt} /$ & 90 & 275 & 289 \\
$/ \mathrm{kk} /$ & 14 & 97 & 162 \\
$/ \mathrm{bb} /$ & 35 & 44 \\
$/ \mathrm{dd} /$ & 9 & 0 & 70 \\
$/ \mathrm{gg} /$ & 70 & 0 & 12 \\
Total & 12 & 946 & 2,349 \\
\hline
\end{tabular}

of the first difference of the intensity contour between the midpoint of the consonant and the midpoint of the following vowel. More lenited consonants have a less abrupt transition irrespective of the time from the intensity minimum to the intensity maximum.

The IntDiff value of a given token will depend not only on how much energy there is during the consonantal constriction, but also, in part, on the intensity of the following vowel. It would thus not be entirely appropriate, for instance, to use IntDiff to compare the degree of constriction of the same consonant before stressed and unstressed vowels, since stress is known to affect intensity. Vowel height is also known to have an effect on intensity, so that, other things being equal, higher vowels are less intense than lower vowels [Lehiste and Peterson, 1959; Lehiste, 1970]. In Hualde et al. [2010], IntDiff and our other measurement, MaxVel, which does not depend on the intensity of the following vowel to the same extent, are shown to give very similar results. In Hualde et al. [2011] a very good correlation is found between these two acoustic measurements. In addition, Parrell [2010] found a very strong correlation between both of these acoustic measurements and articulatory data of degree of constriction for Spanish /b/. For these reasons, we feel justified in considering IntDiff as a valid possible acoustic correlate reflecting differences in degree of constriction in our data. As in previous studies, we expect to find IntDiff and MaxVel to return similar results. At the end of section 3.3 we consider the possible influence of lexical stress and vowel height for the interpretation of our IntDiff results.

\section{Results}

\subsection{Voicing: 'Voiced' and 'Voiceless' Allophones}

The number of tokens that we have obtained for each consonant is given in table 1 . For word-internal consonants the classification has been orthographically determined. As already mentioned, it has been noted that in Rome Italian intervocalic /b/tends to be realized as geminate, both word-internally and across word boundaries, so that the distinction between $/ \mathrm{b} /$ and $/ \mathrm{bb} /$ may be only of etymological or orthographic interest. Notice that we have not found any instances of $-d d$ - or $-g g$ - in our corpus (which are relatively rare geminates). 
Table 2. Realizations of intervocalic $/ \mathrm{p} \mathrm{t} \mathrm{k/}$

\begin{tabular}{llllll}
\hline Consonant & $\begin{array}{l}\text { Voiceless } \\
\text { stop }\end{array}$ & $\begin{array}{l}\text { Voiced stop/ } \\
\text { approximant }\end{array}$ & Deleted & $\begin{array}{l}\text { Voiceless } \\
\text { fricative }\end{array}$ & Affricate \\
\hline$/ \mathrm{p} /$ & $198(44 \%)$ & $250(55.56 \%)$ & $2(0.44 \%)$ & 0 & 0 \\
$/ \mathrm{t} /$ & $120(48.39 \%)$ & $121(48.79 \%)$ & $4(1.61 \%)$ & $1(0.40 \%)$ & $2(0.81 \%)$ \\
$/ \mathrm{k} /$ & $127(30.83 \%)$ & $268(65.05 \%)$ & $13(3.16 \%)$ & $4(0.97 \%)$ & 0 \\
Total & 445 & 639 & 19 & 5 & 2 \\
\hline
\end{tabular}

Number of tokens and percentages of each of the realizations. The category 'voiced' includes stops and approximants.

Word-initial consonants have been classified as geminate if they occurred in the context of RS without pause or break between the two words. As mentioned before, RS is said to take place in two distinct contexts, after a stressed vowel (e.g. tre [dd]ita 'three fingers', un po [kk] urvo 'a little curved') and after a small set of function words without final stress (e.g. $a$ [dd]estra 'to the right', qualche [kk]osa 'anything'). In determining the lexical triggers of RS we have followed Loporcaro [1997, pp. 1-2], Borrelli [2002, pp. 25-28], and Absalom et al. [2002], taking into account the specific comments in these sources for Rome Italian.

Word-internal geminates /pp tt kk/ were never voiced in our corpus [on the lenition of geminates, see Kirchner, 2000], but we found 17 instances of voicing of $/ \mathrm{p} / \mathrm{or} / \mathrm{k} / \mathrm{in}$ the context of RS, out of 169 tokens of $/ \mathrm{p} \mathrm{t} \mathrm{k}$ / in this context. This is a sporadic occurrence that has also been noticed by other authors [Bernhard, 1998]. Voiced geminates, including orthographic singleton $b$, were sometimes realized with incomplete voicing.

The distribution of allophones of singleton $/ \mathrm{p} \mathrm{t} \mathrm{k}$, which are the main focus of this paper, is shown in table 2 . Nearly all tokens of $/ \mathrm{p} \mathrm{t} \mathrm{k/} \mathrm{in} \mathrm{our} \mathrm{corpus} \mathrm{can} \mathrm{be} \mathrm{classified} \mathrm{as}$ belonging to two major classes 'voiceless stop' or 'voiced stop or approximant/fricative'. Other types (voiceless fricative, affricate, deleted) are very rare.

Table 2 shows that over $55 \%$ of all occurrences of intervocalic $/ \mathrm{p} /$ and over $48 \%$ of those of $/ \mathrm{t} /$ were phonetically 'voiced', whereas in the case of $/ \mathrm{k} /$ we find $65 \%$ of 'voiced' realizations in our corpus. Recall that cases with voicing not extending throughout the consonantal constriction have been classified as 'voiceless'. In table 2 the column 'voiceless stops' thus includes tokens with partial voicing. The category 'voiced' includes voiced stops and voiced approximants and fricatives. We have chosen not to separate these subtypes of voiced allophones by visual inspection of spectrograms [as it is done in, e.g., Martínez-Celdrán and Regueira, 2008, for Galician], but rather to use continuous measurements to infer degree of constriction.

Notice that the number of tokens of intervocalic $/ \mathrm{p} \mathrm{t} \mathrm{k/} \mathrm{realized} \mathrm{as} \mathrm{voiceless} \mathrm{frica-}$ tives is exceedingly small. Lenition of these phonemes in Rome Italian thus has very different characteristics from its Tuscan counterpart [Marotta, 2008, and other references cited above].

In table 1 , in the 'Appendix', we show the distribution of allophones of $/ \mathrm{p} \mathrm{t} \mathrm{k}$ / classified according to the nature of the immediately following segment. As can be seen there, there is a considerable percentage of voiced realizations of $/ \mathrm{p} /, / \mathrm{t} /$ and $/ \mathrm{k} /$ in all contexts, always higher than a third of tokens in any given context, and reaching over $80 \%$ in the case of $/ \mathrm{k} /$ before front mid vowels and liquids. In subsequent acoustic

$\overline{220} \quad \overline{\text { Phonetica 2011;68:215-242 }} \quad$ Hualde/Nadeu 


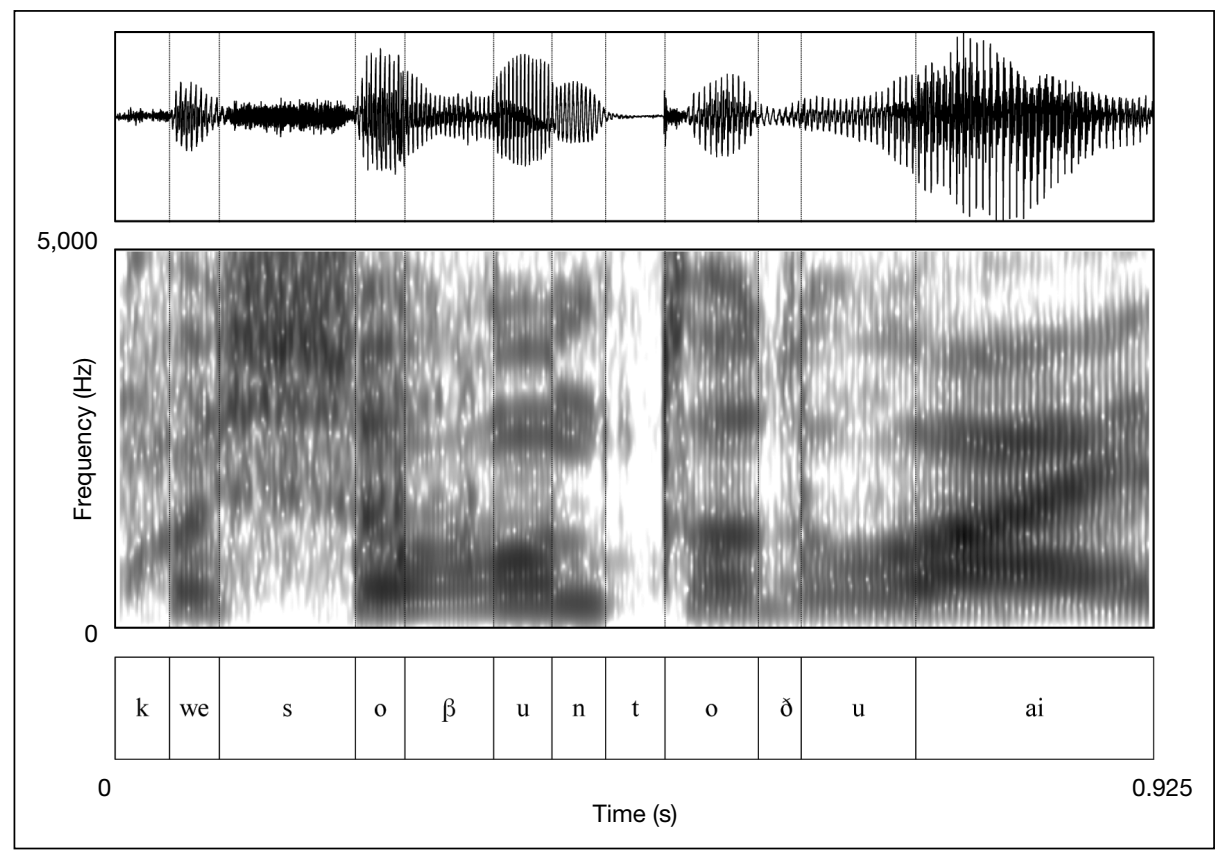

Fig. 1. Spectrogram of part of the utterance A questo punto tu hai (delle sferette colorate) 'At this point you have small red spheres'. Notice the lenition of $/ \mathrm{p} /$ in punto and $/ \mathrm{t} /$ in $t u$.

analyses of allophones of $/ \mathrm{p} \mathrm{t} \mathrm{k/,} \mathrm{we} \mathrm{will} \mathrm{exclude} \mathrm{voiceless} \mathrm{fricatives,} \mathrm{voiceless} \mathrm{affri-}$ cates and completely deleted consonants, given their very small number $(26=2.4 \%$

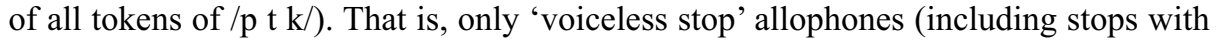
incomplete voicing) and 'voiced' realizations (including voiced stops, fricatives and approximants) will be taken into account.

Figure 1 illustrates the weakening of intervocalic voiceless stops. Figure 2 shows both the weakening of /-p-/ and the strengthening of /-b-/.

Separating the tokens of $/ \mathrm{p} \mathrm{t} \mathrm{k/} \mathrm{in} \mathrm{table} 2$ as word-initial (after a vowel) and wordinternal, we obtain the results in table 3 . As shown in table 3 , for $/ \mathrm{p} /$ and $/ \mathrm{t} /$ the percentage of voiced realizations is greater in word-internal than in word-initial position. For $/ \mathrm{k} /$, on the other hand, there is a slightly greater percentage of voiced realizations wordinitially. The difference between the two positions is small in the case of $/ \mathrm{k} /$, which is the segment with the largest overall degree of voicing, but larger for $/ \mathrm{p} /$ and $/ \mathrm{t} /$. This difference between contexts is statistically significant for $/ \mathrm{p} /\left[\chi^{2}(1)=4.64, \mathrm{p}<0.05\right]$, and $/ \mathrm{t} /\left[\chi^{2}(1)=11.77, \mathrm{p}<0.001\right]$, but not for $/ \mathrm{k} /\left[\chi^{2}(1)=0.18, \mathrm{NS}\right]$.

Clearly phonetic voicing per se does not consistently distinguish the two series of singleton phonemes in intervocalic position, since $/ \mathrm{p} \mathrm{t} \mathrm{k/} \mathrm{are} \mathrm{fully} \mathrm{voiced} \mathrm{roughly}$ as frequently as they are voiceless or only partially voiced (table 2), with differences depending on point of articulation. Table 3 shows that for intervocalic/t/ voiced realizations are more frequent than voiceless ones only in word-medial position, but for intervocalic $/ \mathrm{p} /$ and $/ \mathrm{k} /$ there is a preference for voiced realizations both word-medially and word-initially. 


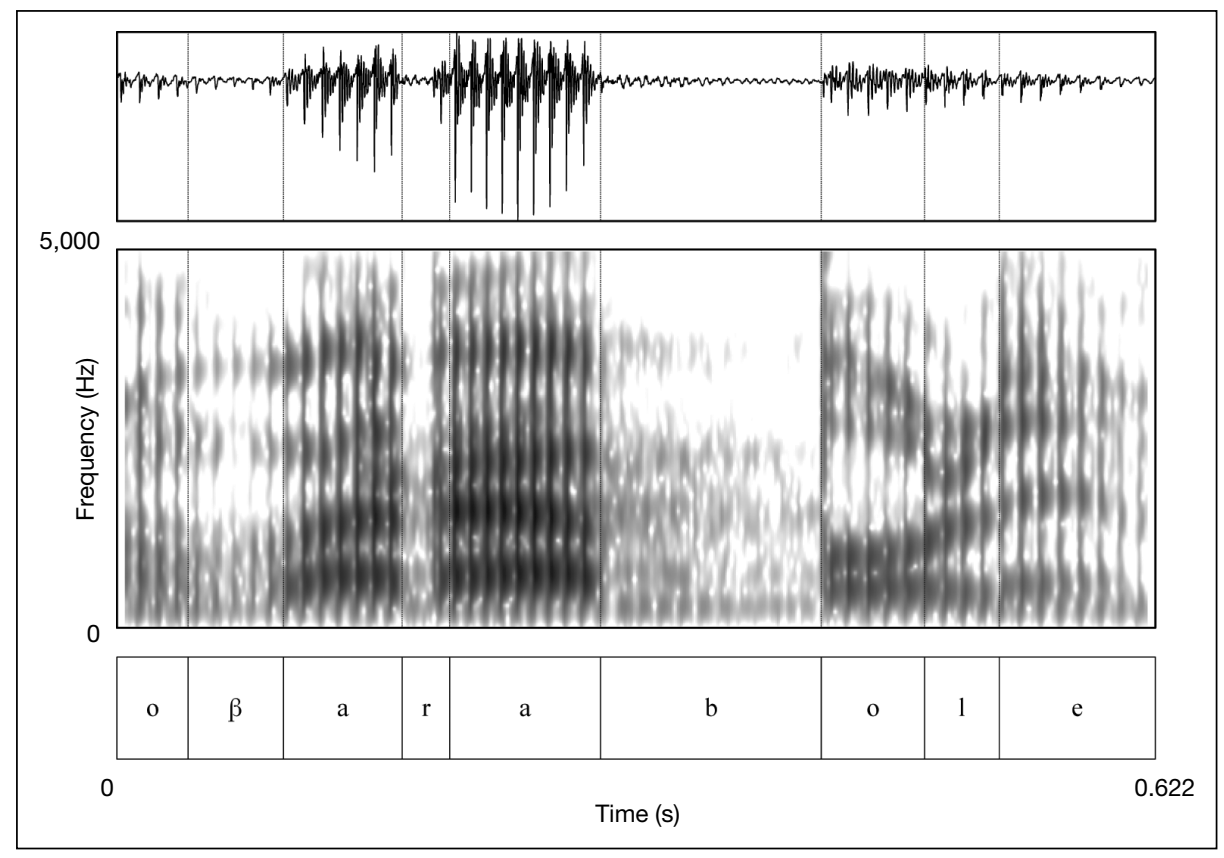

Fig. 2. Spectrogram of part of the utterance (Como si chiamavan)o(?) parabole 'What did you call them(?) parabolas'. Notice the lenition of the word-initial intervocalic /p/ and the gemination of the /b/. (The speaker pronounced chiamavano parabole without intervening pause, in spite of what the conventional punctuation would suggest.)

Table 3. Voiceless stop' and 'voiced stop or approximant/fricative' realizations of word-internal and word-initial intervocalic $/ \mathrm{p} \mathrm{t} \mathrm{k/}$

\begin{tabular}{llllllll}
\hline $\begin{array}{l}\text { Word- } \\
\text { initial }\end{array}$ & $\begin{array}{l}\text { Voiceless } \\
\text { stop }\end{array}$ & $\begin{array}{l}\text { Voiced } \\
\text { stop/ } \\
\text { approxi- } \\
\text { mant }\end{array}$ & Other & $\begin{array}{l}\text { Word- } \\
\text { internal }\end{array}$ & $\begin{array}{l}\text { Voiceless } \\
\text { stop }\end{array}$ & $\begin{array}{l}\text { Voiced } \\
\text { stop/ } \\
\text { approxi- } \\
\text { mant }\end{array}$ & Other \\
\hline$/ \mathrm{p}-/$ & 136 & 147 & 2 & /-p-/ & 62 & 103 & 0 \\
& $(47.72 \%)$ & $(51.58 \%)$ & $(0.70 \%)$ & & $(37.58 \%)$ & $(62.42 \%)$ & \\
$/ \mathrm{t}-/$ & 67 & 40 & 3 & $/$-t-/ & 53 & 81 & 4 \\
& $(60.91 \%)$ & $(36.36 \%)$ & $(2.73 \%)$ & & $(38.41 \%)$ & $(58.70 \%)$ & $(2.90 \%)$ \\
$/ \mathrm{k}-/$ & 104 & 224 & 9 & $/-\mathrm{k}-/$ & 23 & 44 & 8 \\
& $(30.86 \%)$ & $(66.47 \%)$ & $(2.67 \%)$ & & $(30.67 \%)$ & $(58.67 \%$ & $(10.67 \%)$ \\
Total & 307 & 411 & 14 & & 138 & 228 & 12 \\
\hline
\end{tabular}

The category 'voiceless stop' includes partially voiced tokens. The category 'other' includes deleted, voiceless fricative and voiceless affricate realizations (see table 2). Number of tokens and percentages of each of the realizations. 


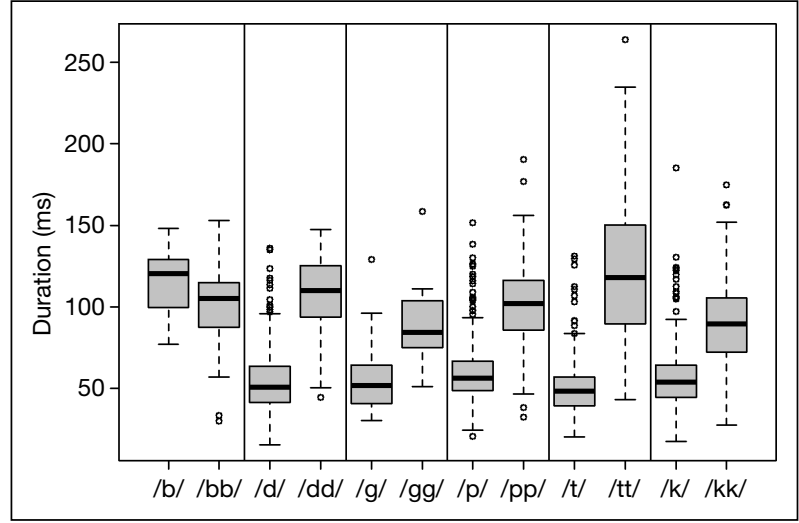

Fig. 3. Boxplots of duration (in milliseconds) of singleton and geminate voiced and voiceless plosives.

The large percentage of voiced realizations of intervocalic $/ \mathrm{p} \mathrm{t} \mathrm{k/} \mathrm{naturally} \mathrm{raises}$ the question of how and to what extent the contrast with phonological $/ \mathrm{b} \mathrm{d} \mathrm{g/} \mathrm{is} \mathrm{main-}$ tained in Rome Italian when $/ \mathrm{p} \mathrm{t} \mathrm{k}$ / are realized as voiced. To try to provide an answer to the question we have examined duration and degree of constriction (as manifested in the intensity curve) as possible cues to the contrast between the two phonological series.

In Italian, differences in duration in intervocalic consonants are known to be primarily related to the opposition between singleton and geminate consonants [Pickett et al., 1999; Payne, 2005]. The analysis of duration as a possible correlate distinguishing $/ \mathrm{p} \mathrm{t} \mathrm{k/} \mathrm{from} / \mathrm{b} \mathrm{d} \mathrm{g/,} \mathrm{even} \mathrm{when} / \mathrm{p} \mathrm{t} \mathrm{k}$ / show vocal fold vibration, requires thus considering also the distinction between singleton and geminate plosives. We turn to the duration results in the next subsection.

\subsection{Duration}

In figure 3 we show boxplots of duration for singleton versus geminate plosives, including both word-medial and word-initial tokens. Again, word-initial geminates are those in the context of RS whereas in medial position the classification is based on the standard spelling of words.

First, for the voiceless plosives, /p t k pp tt kk/, mixed-effects regression analysis with duration (in milliseconds) as a response, individual speaker and word as random intercepts, and consonant type (singleton, geminate) and place of articulation (labial, coronal, velar) as fixed factors was followed by an ANOVA summary of the model. The results revealed fixed effects of both consonant type $[(F(1,1,632)=935.19, p<$ $0.001]$ and place of articulation $[\mathrm{F}(2,1,632)=7.88, \mathrm{p}<0.001]$, as well as a significant interaction between the two factors $[\mathrm{F}(2,1,632)=53.77, \mathrm{p}<0.001]$. The data were then submitted to another regression model with the single fixed factor of consonant type. In order to explore the interaction between place of articulation and consonant type, the data were separated into three groups by place of articulation (labial, coronal, velar). Each dataset was submitted to a regression analysis with consonant type as a fixed factor. Table 4 presents the results of these models. The four analyses reveal significant differences between the geminate and the singleton voiceless stops, with /pp 
Table 4. Mixed-effects regression analyses of duration (milliseconds) as a function of consonant type (geminate /pp tt kk/ vs. singleton /p t k/) with speaker and word as random intercepts

\begin{tabular}{llllll}
\hline Analysis & Intercept & Comparison & Beta value & t value & $\mathrm{p}$ value \\
\hline All places & $/ \mathrm{pp} \mathrm{tt} \mathrm{kk} /$ & $/ \mathrm{p} \mathrm{t} \mathrm{k} /$ & -45.51 & -28.16 & $<0.001$ \\
Velars & $/ \mathrm{kk} /$ & $/ \mathrm{k} /$ & -28.52 & -12.45 & $<0.001$ \\
Coronals & $/ \mathrm{tt} /$ & $/ \mathrm{t} /$ & -68.78 & -20.27 & $<0.001$ \\
Labials & $/ \mathrm{pp} /$ & $/ \mathrm{p} /$ & -39.33 & -16.46 & $<0.001$ \\
\hline
\end{tabular}

Table 5. Mixed-effects regression analyses of duration (milliseconds) as a function of consonant type (geminate /bb dd gg/ vs. singleton /b d g/) with speaker and word as random intercepts

\begin{tabular}{llllrl}
\hline Analysis & Intercept & Comparison & Beta value & t value & $\mathrm{p}$-value \\
\hline All places & /bb dd gg/ & $/ \mathrm{b} \mathrm{d} \mathrm{g} /$ & -44.89 & -18.61 & $<0.001$ \\
Velars & $/ \mathrm{gg} /$ & $/ \mathrm{g} /$ & -36.70 & -6.17 & $<0.001$ \\
Coronals & $/ \mathrm{dd} /$ & $/ \mathrm{d} /$ & -48.76 & -19.68 & $<0.001$ \\
Labials & $/ \mathrm{bb} /$ & $/ \mathrm{b} /$ & 10.39 & 2.11 & $<0.05$ \\
\hline
\end{tabular}

tt kk/ being longer than the singleton consonants /p t k/ [cf. Pickett et al., 1999; Payne, 2005].

The same analysis was performed for the voiced plosives. The ANOVA summary of the mixed-effects regression model yielded fixed effects of both consonant type $[\mathrm{F}(1$, $705)=444.25, \mathrm{p}<0.001]$ and place of articulation $[\mathrm{F}(2,705)=125.78, \mathrm{p}<0.001]$, as well as a significant interaction between the two factors $[\mathrm{F}(2,705)=53.17, \mathrm{p}<0.001]$. The same follow-up analyses with the single fixed effect of consonant type were carried out (both for all the data taken together, as well as for the data separated by place of articulation, given the significant interaction between the two factors). The results are shown in table 5 . The analysis without separating by place shows that geminates are significantly longer than singleton consonants. Separating by place, this result obtains for the velar $/ \mathrm{g} /-/ \mathrm{gg} /$ and coronal $/ \mathrm{d} /-/ \mathrm{dd} /$ consonants. It should be remembered that all of our tokens of $/ \mathrm{dd} /$ and $/ \mathrm{gg} /$ are word-initial, as we did not find any instances of these word-medial geminates in our corpus. The fact that this durational difference was found indicates that the application of RS in the contexts specified in the literature was consistent enough to produce the observed effect when the data are separated in this manner.

For the voiced labials, the tokens that were placed in the singleton category, which includes all tokens of word-medial orthographic $-b$ - as well as tokens of $b$-outside of the context of RS, are somewhat longer than the geminate counterparts (including medial orthographic $-b b$ - and initial $b$ - not in the context of RS). As can be seen from the boxplots in figure 3 , both $b$ and $b b$ are, nevertheless, within the range of other geminate consonants. Our data thus support the observation that intervocalic $/ \mathrm{b} /$ is geminated in Rome Italian, with loss of the singleton/geminate contrast for this segment. The statistical difference that was found between the two groups (in the opposite direction than that suggested by the orthography) is only found for word-medial tokens (fig. 4) and is likely to be a spurious result due to the fact that we found only 9 tokens of word-medial orthographic $b b$.

$\overline{224} \quad \overline{\text { Phonetica 2011;68:215-242 }}$ Hualde/Nadeu




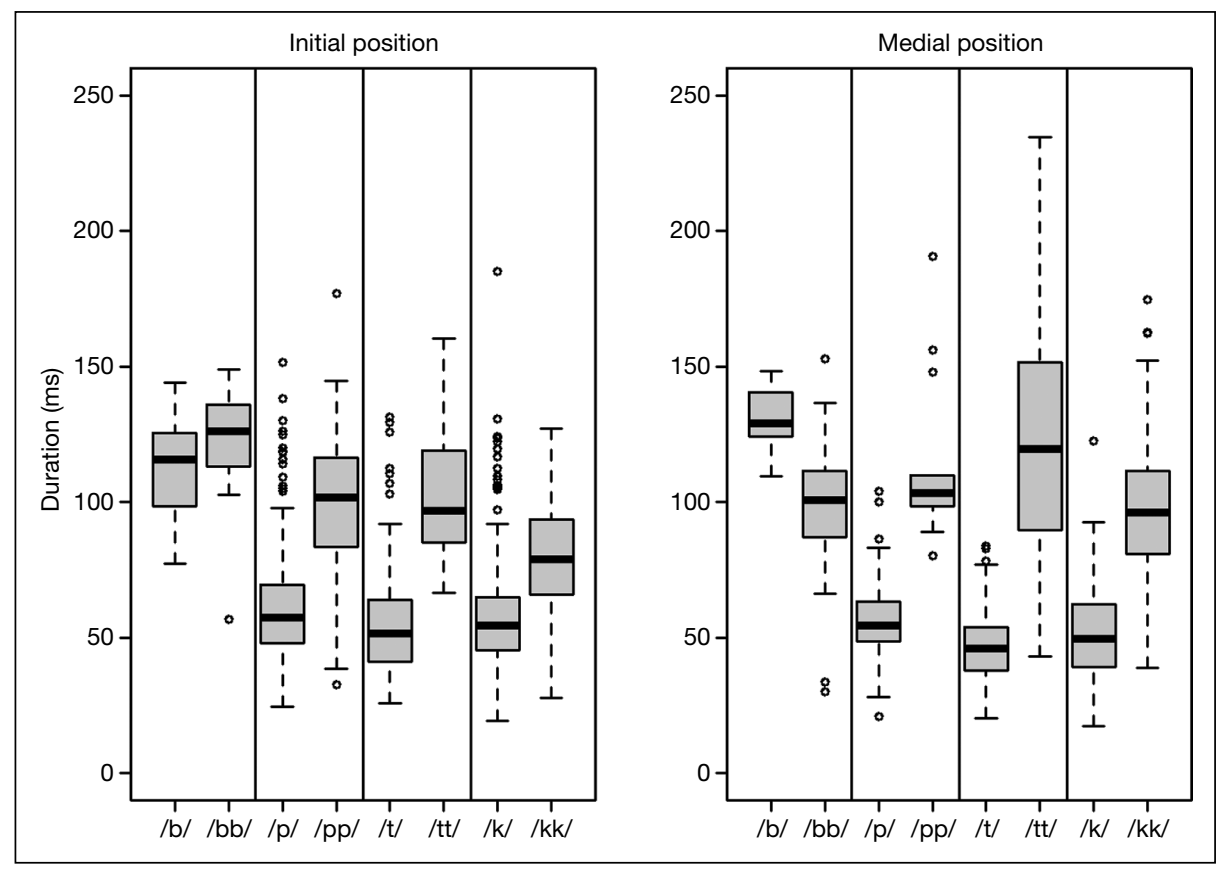

Fig. 4. Boxplots of duration (in milliseconds) of singleton and geminate voiced and voiceless geminates, separating by position in word. (No instances of medial /dd/ or /gg/ were found.)

Stevens and Hajek [2005] report that word-medial geminates and word-initial geminates in the context of RS are not different in Siena Italian [see also Ladd and Scobbie, 2003 for Sardinian]. As reported in the preceding subsection, we found a handful of cases of voicing of consonants in the context of RS, but no instances of voicing of word-medial phonologically voiceless geminates. Regarding duration, the relationship between voiceless singleton and geminate consonants is substantially the same in both positions, as can be seen in the boxplots in figure 4, but the word-medial geminates are somewhat longer than the segments in the context of RS in our data. An explanation of these facts may be sporadic failure to apply gemination in the context of RS.

No further analysis of geminates is offered here since the focus of the paper, to which we turn now, is the lenition of singleton $/ \mathrm{p} \mathrm{t} \mathrm{k/} \mathrm{and} \mathrm{its} \mathrm{possible} \mathrm{overlap} \mathrm{with} / \mathrm{b}$ $\mathrm{d} g /$. The analysis up to this point has served to establish that duration reliably distin-

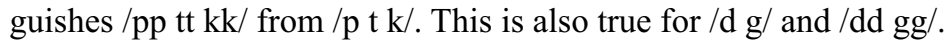

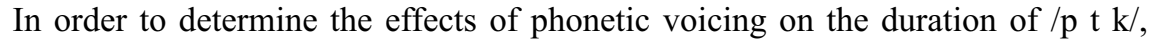
'voiced' and 'voiceless' tokens of these phonemes were separated. The boxplots in figure 5 show the difference in duration between intervocalic 'voiced' and 'voiceless' $/ \mathrm{p} \mathrm{t}$ $\mathrm{k} /$ and phonemic /b d g/ (both word-internal and word-initial).

Visual inspection of the boxplots in figure 5 suggests that the 'voiced' allophones of $/ \mathrm{p} \mathrm{t} \mathrm{k/} \mathrm{are} \mathrm{shorter} \mathrm{than} \mathrm{the} \mathrm{'voiceless'} \mathrm{allophones} \mathrm{of} \mathrm{the} \mathrm{same} \mathrm{phonemes.} \mathrm{That} \mathrm{is,}$ lenition or weakening of these segments would appear to result in their shortening and voicing. 


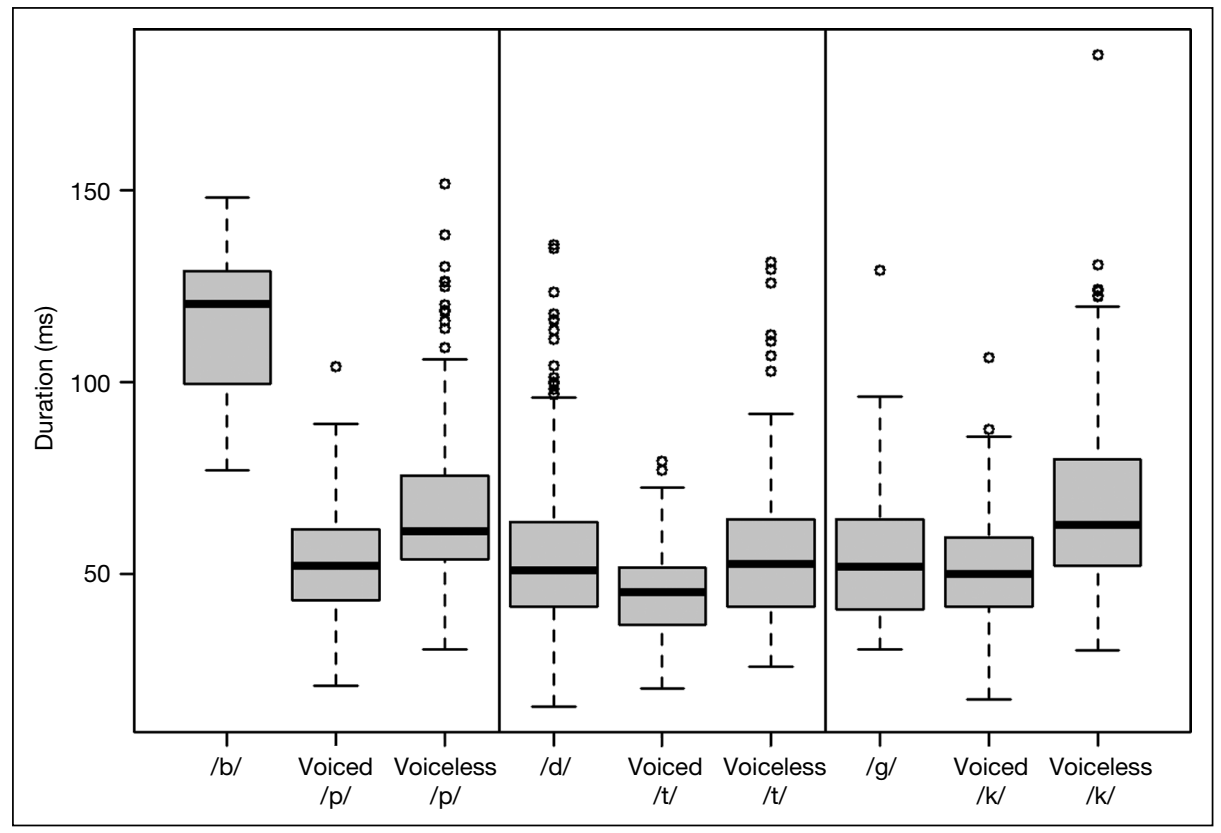

Fig. 5. Boxplots of duration (in milliseconds) of $/ \mathrm{b} \mathrm{d} \mathrm{g/,} \mathrm{voiced} \mathrm{tokens} \mathrm{of} / \mathrm{p} \mathrm{t} \mathrm{k/} \mathrm{and} \mathrm{voiceless} \mathrm{tokens}$ of $/ \mathrm{p} \mathrm{t} \mathrm{k/.}$

The data were submitted to a mixed-effects regression analysis with duration (in milliseconds) as a response, individual speaker and word as random intercepts, and voicing type (phonemic $/ \mathrm{b} \mathrm{d} \mathrm{g/,} \mathrm{voiced} / \mathrm{p} \mathrm{t} \mathrm{k/} \mathrm{and} \mathrm{voiceless} / \mathrm{p} \mathrm{t} \mathrm{k} /$ ) and place of articulation (bilabial, coronal, velar) as fixed factors. An ANOVA summary of the model showed fixed effects of both voicing type $[\mathrm{F}(2,1,660)=116.00, \mathrm{p}<0.001]$ and place of articulation $[\mathrm{F}(2,1,660)=77.03, \mathrm{p}<0.001]$, and a significant interaction between the two factors $[F(4,1,660)=68.68, \mathrm{p}<0.001]$. In order to explore the fixed effect of voicing, the data were submitted to two regression models with the single fixed factor of voicing type. Using two regression models, each with a different intercept, allowed us to test for the three pairwise comparisons. Lastly, the interaction between place of articulation and voicing type was also explored. The data were separated into three datasets by place of articulation. Each dataset was submitted to two regression analyses (using two different intercepts) with voicing type as a fixed factor; $p$ values were obtained through Markov Chain Monte Carlo sampling [Baayen, 2008]. The results of these models can be found in table 6 .

The results of the analysis of duration with all the data indicate that voiced realizations of $/ \mathrm{p} \mathrm{t} \mathrm{k/} \mathrm{are} \mathrm{significantly} \mathrm{different} \mathrm{both} \mathrm{from} / \mathrm{b} \mathrm{d} \mathrm{g/} \mathrm{and} \mathrm{from} \mathrm{voiceless} \mathrm{realiza-}$

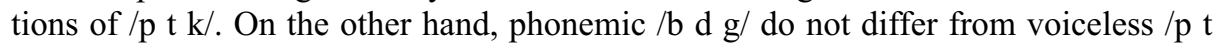
$\mathrm{k} /$ when all three points of articulation are considered together. However, the boxplots in figure 5 make clear that, regarding the duration of underlyingly voiced consonants, all three points of articulation do not behave uniformly. The separate models by place of articulation show that the three pairwise comparisons are significant for the labials. 
Table 6. Mixed-effects regression analyses of duration (milliseconds) as a function of voicing type

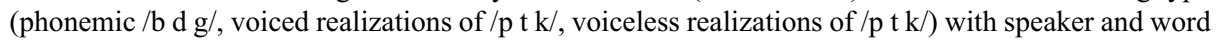
as random intercepts

\begin{tabular}{|c|c|c|c|c|c|}
\hline Analysis & Intercept & Comparison & Beta value & $\mathrm{t}$ value & $\mathrm{p}$ value \\
\hline \multirow[t]{3}{*}{ All places } & $/ \mathrm{b} \mathrm{d} \mathrm{g/}$ & voiced /p t k/ & -13.79 & -7.86 & $<0.001$ \\
\hline & $/ \mathrm{b} \mathrm{d} \mathrm{g/}$ & voiceless /p t k/ & -1.60 & -0.88 & NS \\
\hline & voiced /p t k/ & voiceless /p t k/ & 12.19 & 10.16 & $<0.001$ \\
\hline \multirow[t]{3}{*}{ Velars } & $/ g /$ & voiced $/ \mathrm{k} /$ & -3.91 & -1.26 & NS \\
\hline & /g/ & voiceless /k/ & 9.35 & 2.88 & $<0.01$ \\
\hline & voiced /k/ & voiceless /k/ & 13.26 & 7.07 & $<0.001$ \\
\hline \multirow[t]{3}{*}{ Coronals } & $/ \mathrm{d} /$ & voiced /t/ & -9.23 & -4.36 & $<0.001$ \\
\hline & $/ \mathrm{d} /$ & voiceless /t/ & 0.89 & 0.41 & NS \\
\hline & voiced /t/ & voiceless /t/ & 10.12 & 4.48 & $<0.001$ \\
\hline \multirow[t]{3}{*}{ Labials } & $/ \mathrm{b} /$ & voiced /p/ & -63.31 & -20.44 & $<0.001$ \\
\hline & $/ \mathrm{b} /$ & voiceless /p/ & -49.34 & -15.67 & $<0.001$ \\
\hline & voiced /p/ & voiceless /p/ & 13.96 & 8.45 & $<0.001$ \\
\hline
\end{tabular}

The coronals show the same pattern than the general models with all the data, and, for the velars, $/ \mathrm{g} /$ is not statistically different from voiced $/ \mathrm{k} /$.

In other words, first of all, the shorter duration of voiced allophones of $/ \mathrm{p} \mathrm{t} \mathrm{k} / \mathrm{with}$ respect to voiceless realizations of the same phonemes that can be observed in figure 5 turns out to be statistically significant. Secondly, regarding the contrast between homorganic phonemes, for the labials, $/ \mathrm{b} /$ is significantly longer than $/ \mathrm{p} /$ and this difference in duration between phonemes increases when $/ \mathrm{p} /$ is voiced. For the coronals there is no significant durational difference between $/ \mathrm{d} /$ and voiceless realizations of $/ t /$, but when $/ t /$ is voiced it is significantly shorter than underlying $/ d /$. For the velars, $\mathrm{g} / \mathrm{is}$ shorter than voiceless realizations of $/ \mathrm{k} /$, but not different from voiced realizations of $/ \mathrm{k} /$.

\subsection{Degree of Constriction: IntDiff and MaxVel}

Like in the previous section, we separate 'voiced' and 'voiceless' allophones of $/ \mathrm{p} \mathrm{t} \mathrm{k} /$ and compare them with phonemic $/ \mathrm{b} \mathrm{d} \mathrm{g/} \mathrm{in} \mathrm{order} \mathrm{to} \mathrm{establish} \mathrm{to} \mathrm{what}$ extent phonetically voiced $/ \mathrm{p} \mathrm{t} \mathrm{k/} \mathrm{differ} \mathrm{from} \mathrm{phonologically} \mathrm{voiced} / \mathrm{b} \mathrm{d} \mathrm{g/} \mathrm{(and}$ from voiceless $/ \mathrm{p} \mathrm{t} \mathrm{k/)} \mathrm{in} \mathrm{degree} \mathrm{of} \mathrm{constriction.} \mathrm{Visual} \mathrm{inspection} \mathrm{of} \mathrm{spectrograms}$ shows that in this Italian variety the phonemes $/ \mathrm{d} /$ and $/ \mathrm{g} /$ also optionally weaken intervocalically and have realizations that can be classified as voiced approximants with variable constriction. The weakening of $/ \mathrm{d} /$ and $/ \mathrm{g} /$, however, does not have the systematicity that it has in Spanish, where intervocalic /b d g/are systematically realized as approximants, as in Rome Italian voiced stop realizations are also common in the same context (fig. 10). Since both phonological series allow voiced realizations with variable degree of constriction when intervocalic, the question arises as to whether there are consistent differences in degree of constriction depending on phonological category.

As mentioned above in section 2, to determine degree of constriction from the acoustic signal we employ two measurements taken from the intensity curve, which 


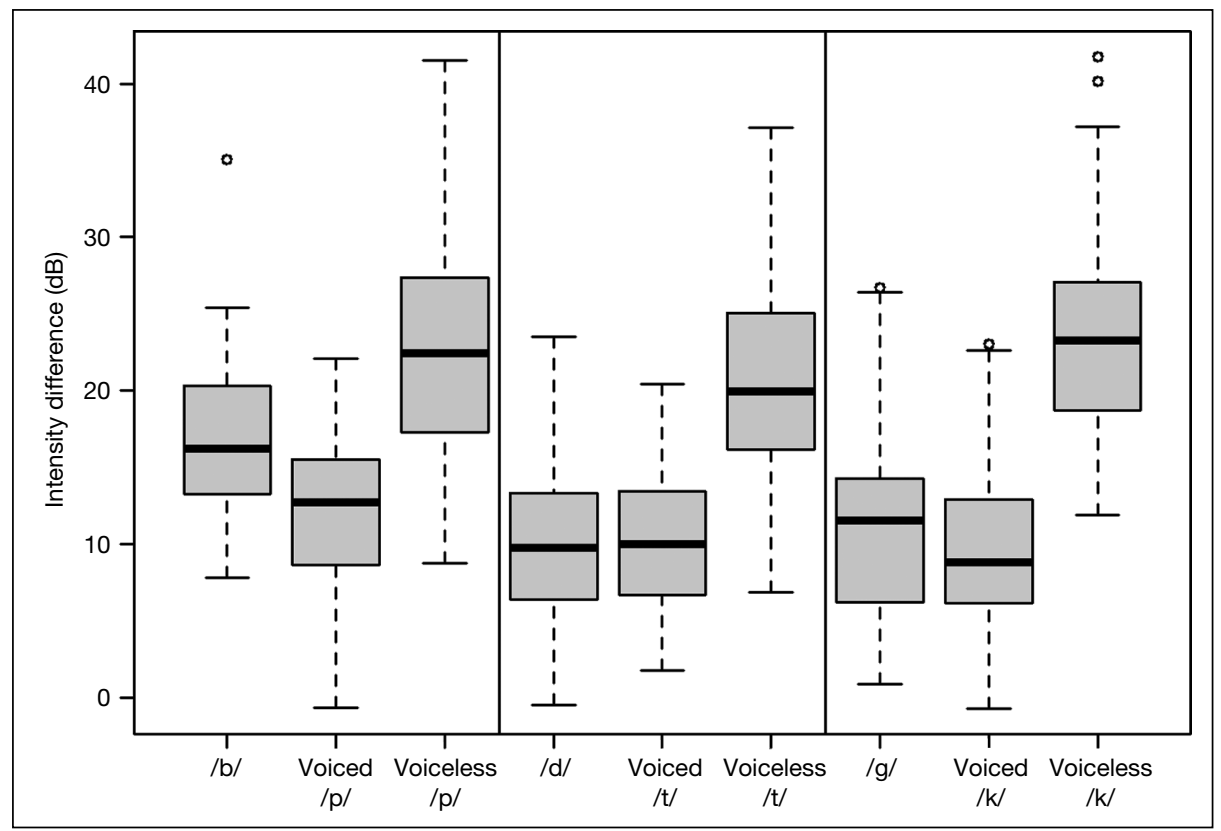

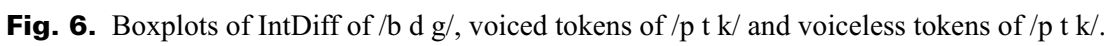

we label IntDiff and MaxVel. The results of our IntDiff measurement are shown in figure 6 .

A mixed-effects regression model was carried out with IntDiff as response, individual speaker and word item as random intercepts, and place of articulation (bilabial,

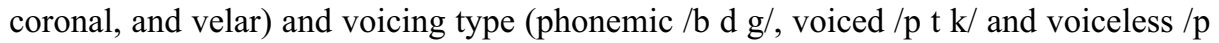
$\mathrm{t} \mathrm{k} /$ ) as fixed factors. An ANOVA summary of the model yielded significant effects of voicing $[\mathrm{F}(2,1,660)=533.77, \mathrm{p}<0.001]$, place of articulation $[\mathrm{F}(2,1,660)=63.48, \mathrm{p}$ $<0.001]$, and a significant interaction $[\mathrm{F}(4,1,660)=9.91, \mathrm{p}<0.001]$.

Two regression models were used to explore the fixed effect of voicing, each assuming a different intercept, and with one single fixed factor, voicing type (phone$\mathrm{mic} / \mathrm{b} \mathrm{d} \mathrm{g/,} \mathrm{voiced} \mathrm{realizations} \mathrm{of} / \mathrm{p} \mathrm{t} \mathrm{k/,} \mathrm{voiceless} \mathrm{realizations} \mathrm{of} / \mathrm{p} \mathrm{t} \mathrm{k/).} \mathrm{After} \mathrm{that,}$ we divided the data into three subsets, one for each place of articulation, to explore the interaction between voicing type and place of articulation found with the first model. Each subset was submitted to a mixed-effects regression model each with the same random intercepts as the main model (speaker and word item) and voicing type (phonemic $/ \mathrm{b} \mathrm{d} \mathrm{g/,} \mathrm{voiced} / \mathrm{p} \mathrm{t} \mathrm{k/,} \mathrm{voiceless} / \mathrm{p} \mathrm{t} \mathrm{k/)} \mathrm{as} \mathrm{a} \mathrm{single} \mathrm{fixed} \mathrm{factor.} \mathrm{The} \mathrm{results} \mathrm{of} \mathrm{the} \mathrm{models}$ are presented in table 7 .

The model with all the data shows that voiced $/ \mathrm{p} \mathrm{t} \mathrm{k/} \mathrm{do} \mathrm{not} \mathrm{differ} \mathrm{from} / \mathrm{b} \mathrm{d} \mathrm{g/,} \mathrm{but}$ the other two comparisons show significant differences. Separating by place, this same pattern is revealed by the analysis of coronal and velar consonants. For labials, all three comparisons find significant differences. Figure 6 shows that, as expected, voiceless realizations of $/ \mathrm{p} \mathrm{t} \mathrm{k}$ / show the greatest values for IntDiff. Our statistical model shows that this is a significant difference with respect to both voiced realizations of the same 


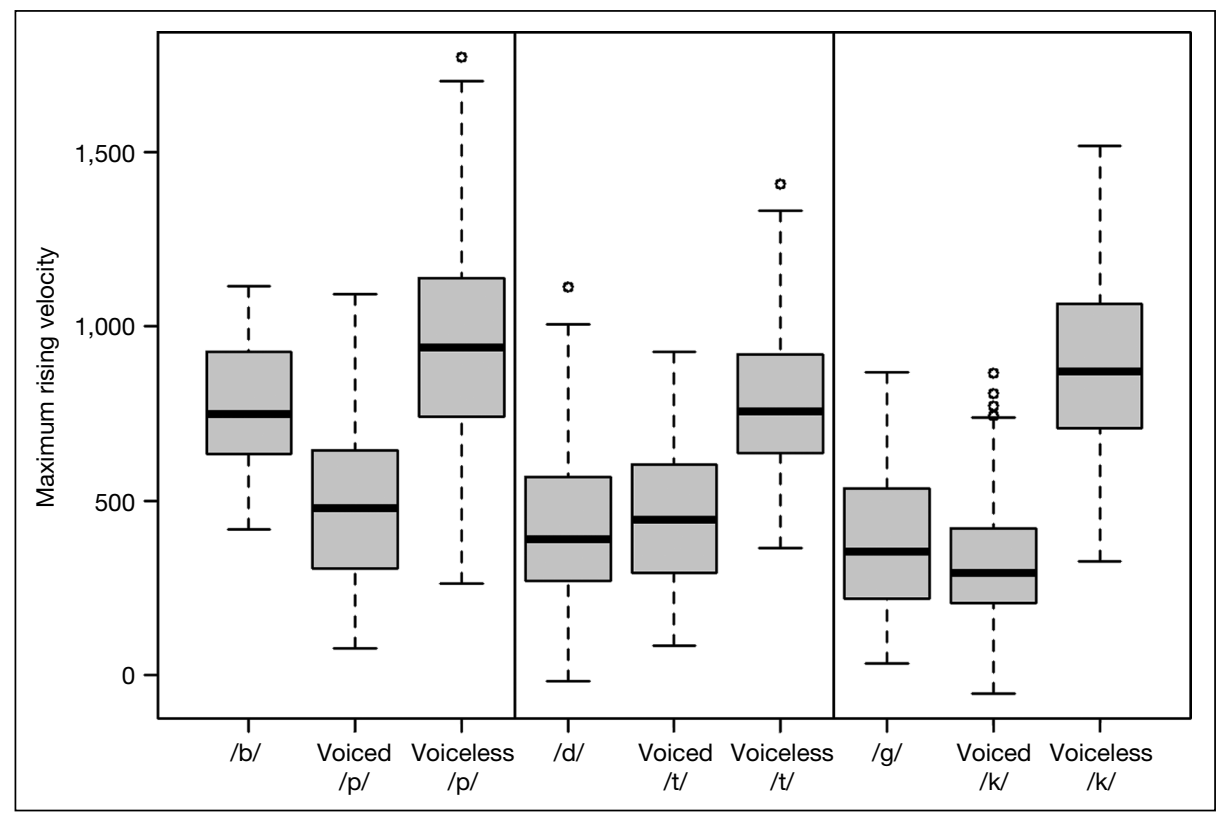

Fig. 7. Boxplots of MaxVel of /b d g/, voiced tokens of $/ \mathrm{p} \mathrm{t} \mathrm{k/} \mathrm{and} \mathrm{voiceless} \mathrm{tokens} \mathrm{of} \mathrm{/p} \mathrm{t} \mathrm{k/.}$

Table 7. Mixed-effects regression analyses of IntDiff as a function of voicing type (phonemic /b d g/,

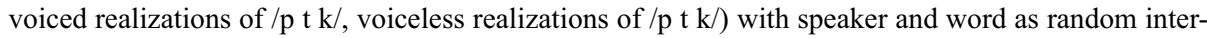
cepts

\begin{tabular}{lllrrl}
\hline Analysis & Intercept & Comparison & Beta value & t value & p value \\
\hline All places & $/ \mathrm{b} \mathrm{d} \mathrm{g/}$ & voiced $/ \mathrm{p} \mathrm{t} \mathrm{k/}$ & 0.35 & 0.85 & $\mathrm{NS}$ \\
& $/ \mathrm{b} \mathrm{d} \mathrm{g/}$ & voiceless $/ \mathrm{p} \mathrm{t} \mathrm{k} /$ & 10.33 & 23.73 & $<0.001$ \\
& voiced $/ \mathrm{p} \mathrm{t} \mathrm{k} /$ & voiceless $/ \mathrm{p} \mathrm{t} \mathrm{k} /$ & 9.98 & 30.10 & $<0.001$ \\
Velars & $/ \mathrm{g} /$ & voiced $/ \mathrm{k} /$ & -1.21 & -1.28 & $\mathrm{NS}$ \\
& $/ \mathrm{g} /$ & voiceless $/ \mathrm{k} /$ & 10.51 & 10.60 & $<0.001$ \\
& $\mathrm{voiced} / \mathrm{k} /$ & voiceless $/ \mathrm{k} /$ & 11.73 & 19.74 & $<0.001$ \\
Coronals & $/ \mathrm{d} /$ & voiced $/ \mathrm{t} /$ & 0.80 & 1.40 & $\mathrm{NS}$ \\
& $/ \mathrm{d} /$ & voiceless $/ \mathrm{t} /$ & 10.31 & 17.46 & $<0.001$ \\
& $\mathrm{voiced} / \mathrm{t} /$ & voiceless $/ \mathrm{t} /$ & 9.51 & 15.43 & $<0.001$ \\
Labials & $/ \mathrm{b} /$ & voiced $/ \mathrm{p} /$ & -4.29 & -4.36 & $<0.001$ \\
& $/ \mathrm{b} /$ & voiceless $/ \mathrm{p} /$ & 4.73 & 4.69 & $<0.001$ \\
& voiced $/ \mathrm{p} /$ & voiceless $/ \mathrm{p} /$ & 9.02 & 18.12 & $<0.001$ \\
\hline
\end{tabular}

phoneme and phonemic $/ \mathrm{b} \mathrm{d} \mathrm{g/.} \mathrm{On} \mathrm{the} \mathrm{other} \mathrm{hand,} \mathrm{regarding} \mathrm{the} \mathrm{comparison} \mathrm{between}$

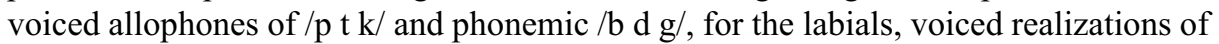
the phoneme $/ \mathrm{p} /$ have lower values than $/ \mathrm{b} /$, whereas voiced realizations of $/ \mathrm{t} /$ and $/ \mathrm{k} /$ do not differ from $/ \mathrm{d} /$ and $/ \mathrm{g} /$, respectively, in IntDiff.

We turn now to our second acoustic measurement of degree of constriction. Figure

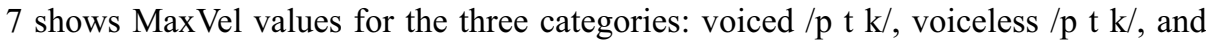


Table 8. Mixed-effects regression analyses of MaxVel as a function of voicing type (phonemic /b d

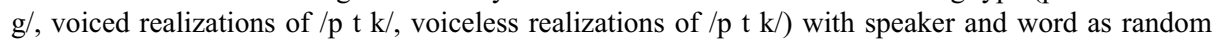
intercepts

\begin{tabular}{|c|c|c|c|c|c|}
\hline Analysis & Intercept & Comparison & Beta value & t value & $\mathrm{p}$ value \\
\hline \multirow[t]{3}{*}{ All places } & $/ \mathrm{b} \mathrm{d} \mathrm{g/}$ & voiced /p t k/ & -18.14 & -1.01 & NS \\
\hline & $/ \mathrm{b} \mathrm{d} \mathrm{g/}$ & voiceless /p t k/ & 400.54 & 21.33 & $<0.001$ \\
\hline & voiced /p t k/ & voiceless /p t k/ & 418.68 & 30.32 & $<0.001$ \\
\hline \multirow[t]{3}{*}{ Velars } & $/ g /$ & voiced $/ \mathrm{k} /$ & -29.58 & -0.86 & NS \\
\hline & /g/ & voiceless /k/ & 462.28 & 12.83 & $<0.001$ \\
\hline & voiced /k/ & voiceless /k/ & 491.86 & 22.62 & $<0.001$ \\
\hline \multirow[t]{3}{*}{ Coronals } & $/ \mathrm{d} /$ & voiced $/ \mathrm{t} /$ & 51.19 & 2.09 & $<0.05$ \\
\hline & $/ \mathrm{d} /$ & voiceless /t/ & 359.95 & 14.29 & $<0.001$ \\
\hline & voiced /t/ & voiceless /t/ & 308.76 & 11.76 & $<0.001$ \\
\hline \multirow[t]{3}{*}{ Labials } & $/ \mathrm{b} /$ & voiced /p/ & -242.07 & -5.55 & $<0.001$ \\
\hline & $/ \mathrm{b} /$ & voiceless /p/ & 179.89 & 4.07 & $<0.001$ \\
\hline & voiced /p/ & voiceless /p/ & 421.96 & 19.10 & $<0.001$ \\
\hline
\end{tabular}

phonemic /b d g/. An ANOVA summary of the mixed-effects regression model with MaxVel as response, speaker and word as random intercepts, and place of articulation and voicing type as fixed factors revealed significant effects of place $[\mathrm{F}(2,1,660)=$ $70.91, \mathrm{p}<0.001]$, voicing $[\mathrm{F}(2,1,660)=533.59, \mathrm{p}<0.001]$, and a significant interaction between the two factors $[\mathrm{F}(4,1,660)=16.14, \mathrm{p}<0.001]$. We repeat the same statistical analyses reported above for IntDiff with the MaxVel data. The results are shown in table 8 .

The results obtained with the models with MaxVel as response agree to a large extent with those obtained with IntDiff as response. The model with all the data returned significant differences between voiced and voiceless $/ \mathrm{p} \mathrm{t} \mathrm{k/} \mathrm{and} \mathrm{between} / \mathrm{b} \mathrm{d} \mathrm{g/} \mathrm{and}$

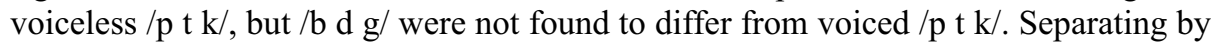
place, velars follow the general pattern, but for labials and coronals all three pairwise comparisons were significant, with $/ \mathrm{b} /$ being more constricted than voiced $/ \mathrm{p} /$, and $/ \mathrm{d} /$ being somewhat less constricted than voiced $/ \mathrm{t} /$.

Putting the results of our two measurements of degree of constriction together,

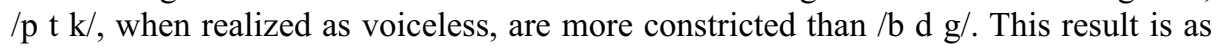
expected, since voiced plosives always have energy due to voicing, which is lacking in voiceless plosives (and they also have energy at higher frequencies when realized without full occlusion). This difference between the two series of phonemes disappears, however, when $/ \mathrm{p} \mathrm{t} \mathrm{k/} \mathrm{are} \mathrm{voiced.} \mathrm{Voiced} \mathrm{tokens} \mathrm{of} / \mathrm{p} /$ are significantly less constricted than $/ \mathrm{b} /$. That is, voiced tokens of $/ \mathrm{p} /$ are frequently realized without full occlusion. For the velars, there is a tendency in the same direction, but the difference does not reach statistical significance for either measurement. For the voiced allophone of $/ \mathrm{t} /$, however, no significant difference with respect to /d/ is found for IntDiff, but MaxVel reveals that it is slightly more constricted than $/ \mathrm{d} /$.

In section 2, we noticed that the IntDiff value of any given token depends not only on the minimum intensity of the consonant but also on the maximum value within the vowel, which may be affected by factors such as stress and vowel height. Given the fact that when applied to our data IntDiff and MaxVel give very similar results, we conclude that such factors, which are difficult to control in a corpus study, have not 
Table 9. Mixed-effects regression analyses of IntDiff with low-pass filtered data as a function of

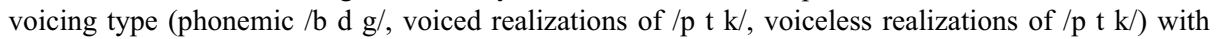
speaker and word as random intercepts

\begin{tabular}{|c|c|c|c|c|c|}
\hline Analysis & Intercept & Comparison & Beta value & t value & $\mathrm{p}$ value \\
\hline \multirow[t]{3}{*}{ All places } & $/ \mathrm{b} \mathrm{d} \mathrm{g/}$ & voiced /p t k/ & 0.91 & 2.72 & $<0.01$ \\
\hline & $/ \mathrm{b} \mathrm{d} \mathrm{g/}$ & voiceless /p t k/ & 9.64 & 27.33 & $<0.001$ \\
\hline & voiced /p t k/ & voiceless /p t k/ & 8.72 & 31.05 & $<0.001$ \\
\hline \multirow[t]{3}{*}{ Velars } & /g/ & voiced $/ \mathrm{k} /$ & 0.62 & 0.90 & NS \\
\hline & /g/ & voiceless /k/ & 10.81 & 14.71 & $<0.001$ \\
\hline & voiced /k/ & voiceless /k/ & 10.19 & 20.54 & $<0.001$ \\
\hline \multirow[t]{3}{*}{ Coronals } & $/ \mathrm{d} /$ & voiced /t/ & 0.73 & 1.58 & NS \\
\hline & $/ \mathrm{d} /$ & voiceless /t/ & 9.37 & 19.82 & $<0.001$ \\
\hline & voiced /t/ & voiceless /t/ & 8.65 & 17.89 & $<0.001$ \\
\hline \multirow[t]{3}{*}{ Labials } & $/ \mathrm{b} /$ & voiced /p/ & -1.15 & -1.23 & NS \\
\hline & $/ \mathrm{b} /$ & voiceless /p/ & 6.66 & 6.98 & $<0.001$ \\
\hline & voiced /p/ & voiceless /p/ & 7.81 & 16.40 & $<0.001$ \\
\hline
\end{tabular}

distorted the IntDiff results. The consideration of the distribution of consonants by context does not reveal any obvious imbalance, either. Tables 2 and 3 in the 'Appendix' show the distribution of the sets of consonants that were considered in the statistics

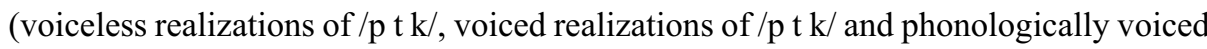
$/ \mathrm{b} \mathrm{d} \mathrm{g/)} \mathrm{separated} \mathrm{by} \mathrm{stress} \mathrm{condition.} \mathrm{As} \mathrm{it} \mathrm{happens,} \mathrm{overall} \mathrm{very} \mathrm{similar} \mathrm{numbers} \mathrm{of}$ tokens were obtained in both conditions ( 808 stressed syllables, 861 unstressed syllables). In table 4 in the 'Appendix', the data are classified according to the height of the tautosyllabic vowel from which the maximum intensity value was obtained to calculate IntDiff.

\subsection{Energy in Low Frequencies}

Albano Leoni and Maturi [1991] find that, in the speech of a speaker of the southern Italian variety of Nusco, intervocalic $/ \mathrm{p} \mathrm{t} \mathrm{k}$ / have less intensity in the voice bar than intervocalic $/ \mathrm{b} \mathrm{d} \mathrm{g} /$ and conclude that $/ \mathrm{p} \mathrm{t} \mathrm{k} /$ are only slightly voiced in this variety. For Rome Italian, Marotta [2005] also states that the lenited allophones of voiceless fricatives have a voice bar of reduced intensity [see also Marotta and Sorianello, 1992]. To test the possibility that there is a difference in low-frequency intensity between the two

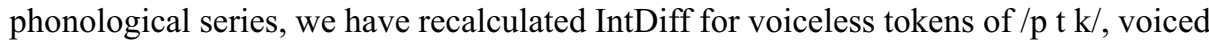
tokens of $/ \mathrm{p} \mathrm{t} \mathrm{k/} \mathrm{and} \mathrm{underlying} \mathrm{/} \mathrm{b} \mathrm{d} \mathrm{g/} \mathrm{after} \mathrm{applying} \mathrm{a} \mathrm{low} \mathrm{pass} \mathrm{filter} \mathrm{with} \mathrm{a} \mathrm{cutoff}$ frequency of $250 \mathrm{~Hz}$. The data are analyzed as before. First, we report the results of the ANOVA summary of the mixed-effects regression model with IntDiff as response, speaker and word as random intercepts, and place of articulation and voicing type as fixed factors. We found significant effects of place $[F(2,1,659)=44.31, p<0.001]$, voicing $[\mathrm{F}(2,1,659)=577.92, \mathrm{p}<0.001]$, and a significant interaction between the two factors $[\mathrm{F}(4,1,659)=4.57, \mathrm{p}<0.001]$. Table 9 shows the results of the two regression models with the sole fixed effect of voicing with all the data, and the pairs of regression models with subsets of data separated by place of articulation, and figure 8 shows IntDiff values for the three categories after applying the filter. 


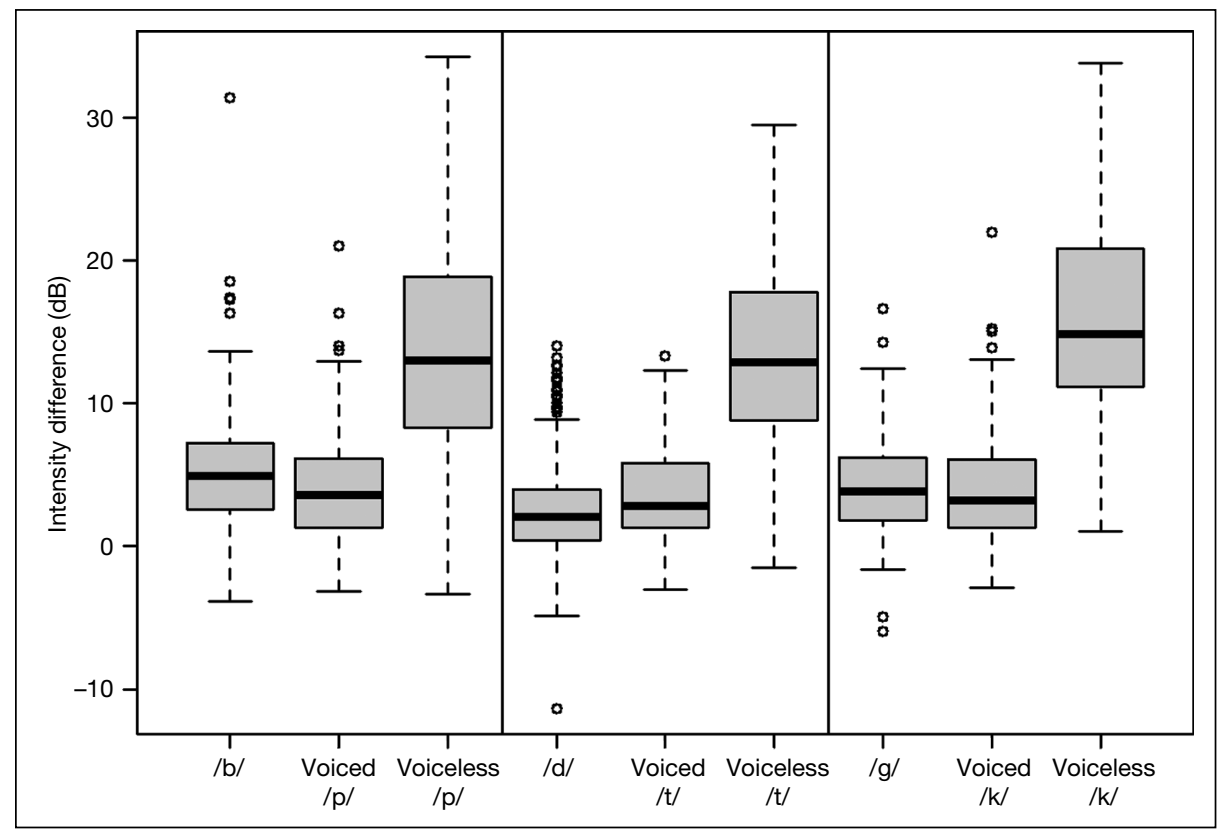

Fig. 8. Boxplots of IntDiff of $/ \mathrm{b} \mathrm{d} \mathrm{g/,} \mathrm{voiced} \mathrm{tokens} \mathrm{of} / \mathrm{p} \mathrm{t} \mathrm{k/} \mathrm{and} \mathrm{voiceless} \mathrm{tokens} \mathrm{of} / \mathrm{p} \mathrm{t} \mathrm{k} /$, after applying a low-pass filter (250-Hz cutoff frequency).

When we compare the difference in intensity between the consonant and the following vowel at frequencies below $250 \mathrm{~Hz}$ of the three groups, we still observe that voiced allophones of $/ \mathrm{p} \mathrm{t} \mathrm{k} /$ do not differ from voiced $/ \mathrm{b} \mathrm{d} \mathrm{g} /$. This is the pattern that emerges from the mixed-effects models performed on separate sets of data according to place of articulation. That is, the amount of energy in low frequencies does not distinguish voiced realizations of the voiceless phonemes from the realizations of the voiced phonemes. The differences between $/ \mathrm{b} \mathrm{d} \mathrm{g/} \mathrm{and} \mathrm{voiceless} \mathrm{allophones} \mathrm{of} / \mathrm{p} \mathrm{t}$

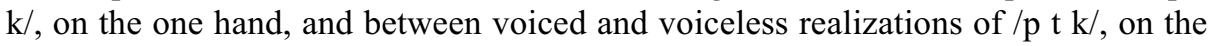
other, are always significant.

\section{Conclusions and Discussion}

We have examined the phonetic realization of the phonological contrast between underlying voiceless and voiced intervocalic plosives in Rome Italian. In this language variety, intervocalic $/ \mathrm{p} \mathrm{t} \mathrm{k}$ / are frequently lenited, both word-medially and across word boundaries. We have shown that the lenition of $/ \mathrm{p} \mathrm{t} \mathrm{k/} \mathrm{involves} \mathrm{their} \mathrm{uninterrupted} \mathrm{voic-}$ ing with a very high frequency. Weakening of intervocalic $/ \mathrm{p} \mathrm{t} \mathrm{k} /$ in Rome Italian has thus taken a very different path than in Florence. Roughly half of the tokens of intervocalic $/ \mathrm{p} \mathrm{t} \mathrm{k/} \mathrm{are} \mathrm{voiced} \mathrm{in} \mathrm{our} \mathrm{sample} \mathrm{of} \mathrm{spontaneous} \mathrm{speech,} \mathrm{but} \mathrm{there} \mathrm{are} \mathrm{exceedingly}$ few examples of voiceless fricatives.

By place of articulation, $/ \mathrm{k} /$ is more often voiced than $/ \mathrm{p} /$ or $/ \mathrm{t} /$. This is the same result that Hualde et al. [2011] found for Spanish. It is also consistent with the fact that 
sporadic voicing of Latin voiceless stops in standard Italian has affected $/ \mathrm{k} /$ more frequently than the other two voiceless stops [Canalis, 2010]. More generally, Recasens [2002] notes that $/ \mathrm{k} /$ shows a greater tendency to voice than the other voiceless stops in Romance.

The percentage of tokens of intervocalic $/ \mathrm{p} \mathrm{t} \mathrm{k/} \mathrm{with} \mathrm{uninterrupted} \mathrm{voicing} \mathrm{is}$ higher than that found in Hualde et al. [2011] for Spanish, as it reaches around $60 \%$ of tokens in medial position. It should be noted that for $/ \mathrm{k} /$, which, as just mentioned, is the segment most prone to voicing, no difference was found between word-medial and word-initial position.

Regarding the opposition between the phonological series /p t k/ and /b d g/, somewhat paradoxically, the result is that $/ \mathrm{p} \mathrm{t} \mathrm{k/may} \mathrm{be} \mathrm{both} \mathrm{stronger} \mathrm{and} \mathrm{weaker} \mathrm{than} / \mathrm{b} \mathrm{d}$ $\mathrm{g} /$. Intervocalically, the voiceless plosives may be realized without lenition, as voiceless, in which case they will have less energy than the phonemic voiced plosives. When lenited, however, the voiceless plosives are very often realized with uninterrupted voicing and these voiced allophones may be as weak or even weaker than the phonemic voiced plosives in the same position, considering both their duration and their degree of constriction. We may thus state that the allophonic range of the intervocalic phonemically voiceless stops includes realizations that are both stronger and weaker than those of the phonemically voiced series. The facts are not the same for all three places of articulation.

Regarding the labials, /p/ differs from /b/ in its duration. Whereas the general cross-linguistic tendency is for voiced plosives to be shorter than voiceless ones, in Rome Italian the opposite is true for the labials, where intervocalic /b/ shows a strong tendency to geminate. The voiced labial is always phonologically long, whereas /-p-/ and /-pp-/ do contrast in length. The lenition of /p/ does not lead to neutralization with $/ \mathrm{b} /$. Voiced tokens of $/ \mathrm{p} /$ are not only shorter than $/ \mathrm{b} /$ but also more open. The phonological opposition in the labials can thus be summarized as follows: /-pp-/ voiceless, long; /-b-/ voiced, long, and /-p-/ (voiceless/voiced), short.

Fortition processes, such as the gemination of $/ \mathrm{b} /$, have less obvious phonetic roots than lenition phenomena. The gemination of $/ b /$ in Rome Italian is the consequence of a complex diachronic development. In Italian, word-internal intervocalic /b/ is relatively rare since in Late Latin word-medial intervocalic $/ \mathrm{b} /$ was weakened to $/ \mathrm{v} /$, as we see in Lat. HABĒRE > It. avere 'to have'. In central and southern Italian varieties, in word-initial position, this weakening of $/ \mathrm{b} /$ appears to have given rise, originally, to an alternation between weak $[\mathrm{v}] \sim[\beta]$ and strong $[\mathrm{b}(\mathrm{b})]$, depending on the context, for the same phoneme. This is still attested in some local dialects, e.g. [ventu] 'wind', [ki bbentu] 'what wind', in the context of RS [Loporcaro, 2009]. Although the phonological contrast between $/ \mathrm{v} /$ and $/ \mathrm{b} /$ was later reestablished in Rome Italian (through the introduction of learned words with - $b$-, etc.), /b/ kept its phonetic character as a 'strong' consonant.

For the other two points of articulation we find a less clear contrast. The degree of weakening of $/ \mathrm{k} /$ and $/ \mathrm{t} /$ and the phonemic overlap with $/ \mathrm{g} /$ and $/ \mathrm{d} /$, respectively, is considerably greater than in Spanish [Hualde et al., 2011].

The velar plosive $/ \mathrm{k} /$, when realized as voiceless, is longer than $/ \mathrm{g} /$, but there is no durational difference when it voices. The voiceless allophones of $/ \mathrm{k} /$ are also more constricted than $/ \mathrm{g} /$, but no differences in degree of constriction were found between $/ \mathrm{g} /$ and voiced realizations of $/ \mathrm{k} /$ in either of our two intensity measurements. We thus seem to have a situation where $/ \mathrm{k} /$ is a phoneme with a wider range 
of realizations than $/ \mathrm{g} /$. Intervocalic $/ \mathrm{k} /$ includes allophones that fall within the range of $/ \mathrm{g} /$ as well as including stronger, voiceless, realizations. Schematically, the allophones of intervocalic $/ \mathrm{k} /$ include all of $[\mathrm{k}] \sim[\mathrm{g}] \sim[\mathrm{\gamma}]$, whereas $/ \mathrm{g} /$ has a narrower range $[\mathrm{g}] \sim[\mathrm{\gamma}]$.

For the coronals, no difference in duration was found between voiceless realizations of $/ \mathrm{t} /$ and $/ \mathrm{d} /$, but $/ \mathrm{t} /$ may become shorter than $/ \mathrm{d} /$ when it undergoes lenition with complete voicing. In the case of the voiced tokens of $/ \mathrm{t} /$, one of our two measurements of degree of constriction (MaxVel) revealed that it was slightly more constricted than underlying $/ \mathrm{d} /$. Voiceless $/ \mathrm{t} /$ is more constricted than $/ \mathrm{d} /$. Again, thus, the allophony of intervocalic $/ \mathrm{t} /$ appears to include much of the range of $/ \mathrm{d} /$ in addition to stronger tokens. That is, in terms of phonetic categories, when in intervocalic position, phoneme $/ \mathrm{t} /$ includes the range $[\mathrm{t}] \sim[\mathrm{d}] \sim[\mathrm{\delta}]$, whereas phoneme $/ \mathrm{d} /$ in the same position has the more restricted range $[\mathrm{d}] \sim[\delta]$. The allophonic range of $/ \mathrm{t} /$ and $/ \mathrm{d} /$ is illustrated in figures 9 and 10, respectively; figure 9 shows two realizations of the phrase la torta 'the pie'. In one of them the word-initial /t/ has been realized as a voiceless stop and in the other as a voiced approximant. For comparisons, figure 10 shows two tokens of /d/ in the word destra 'right hand', one is a voiced stop and the other one a very weak approximant. The crucial difference between the two phonemes is that $/ \mathrm{d} / \mathrm{does}$ not admit a voiceless stop realization.

Pickett et al. [1999] find that the contrast between singleton and geminate consonants is cued in part by the ratio between the duration of the consonant and the duration of the preceding vowel in standard Italian (laboratory speech). In principle, this cue, which we have not measured, could also serve to distinguish phonologically voiced and voiceless plosives, even when the latter are phonetically voiced. There could also be other acoustic cues to the phonological contrast that we have not taken into account and a perception study would be needed in order to test to what extent the contrast between phonologically voiced and voiceless plosives tends to be neutralized in intervocalic position. Notice that, in any case, at most one can speak of a tendency to neutralize the contrast, not of complete neutralization. Even in the case of $/ \mathrm{k} /$, which shows the greatest overlap with its phonologically voiced counterpart according to all measurements, a third of intervocalic tokens are still realized as voiceless in our corpus.

Anecdotal evidence, which we have collected from the literature on the topic, suggests that there is in fact a certain degree of ambiguity between the pairs $/ \mathrm{t} /-\mathrm{d} /$ and $/ \mathrm{k} /-\mathrm{g} /$ in intervocalic word-medial position in actual production in Rome speech. D'Achille [2004] points out, in the case of less common words there is often uncertainty among speakers about the spelling, with a voiced or a voiceless consonant, and regarding the possibility of pronouncing the word with a voiceless plosive, e.g. is it bieta or bièda? 'chard' (beta vulgaris cicla), is it pecorino or pegorino? (for a type of cheese). Bernhard [1998, pp. 66, 91-94, 131-132] also reports on misspellings, hypercorrected pronunciations and puns based on homophony between words containing voiced and voiceless plosives in intervocalic position [e.g. padre d'Erno 'Erno's father' = padre eterno 'eternal father', Bernhard, 1998, p. 92]. The results of our analysis are consistent with these observations.

Compared with the Spanish data on the voicing of intervocalic $/ \mathrm{p} \mathrm{t} \mathrm{k/} \mathrm{reported}$ in Hualde et al. [2011], we thus find several important differences. First of all, the frequency with which $/ \mathrm{p} \mathrm{t} \mathrm{k/} \mathrm{are} \mathrm{voiced} \mathrm{is} \mathrm{much} \mathrm{higher} \mathrm{in} \mathrm{our} \mathrm{Rome} \mathrm{Italian} \mathrm{corpus.}$ Secondly, regarding the contrast wih $/ \mathrm{b} \mathrm{d} \mathrm{g/,} \mathrm{for} \mathrm{the} \mathrm{labials,} \mathrm{the} \mathrm{strengthening} \mathrm{of} / \mathrm{b} /$ 


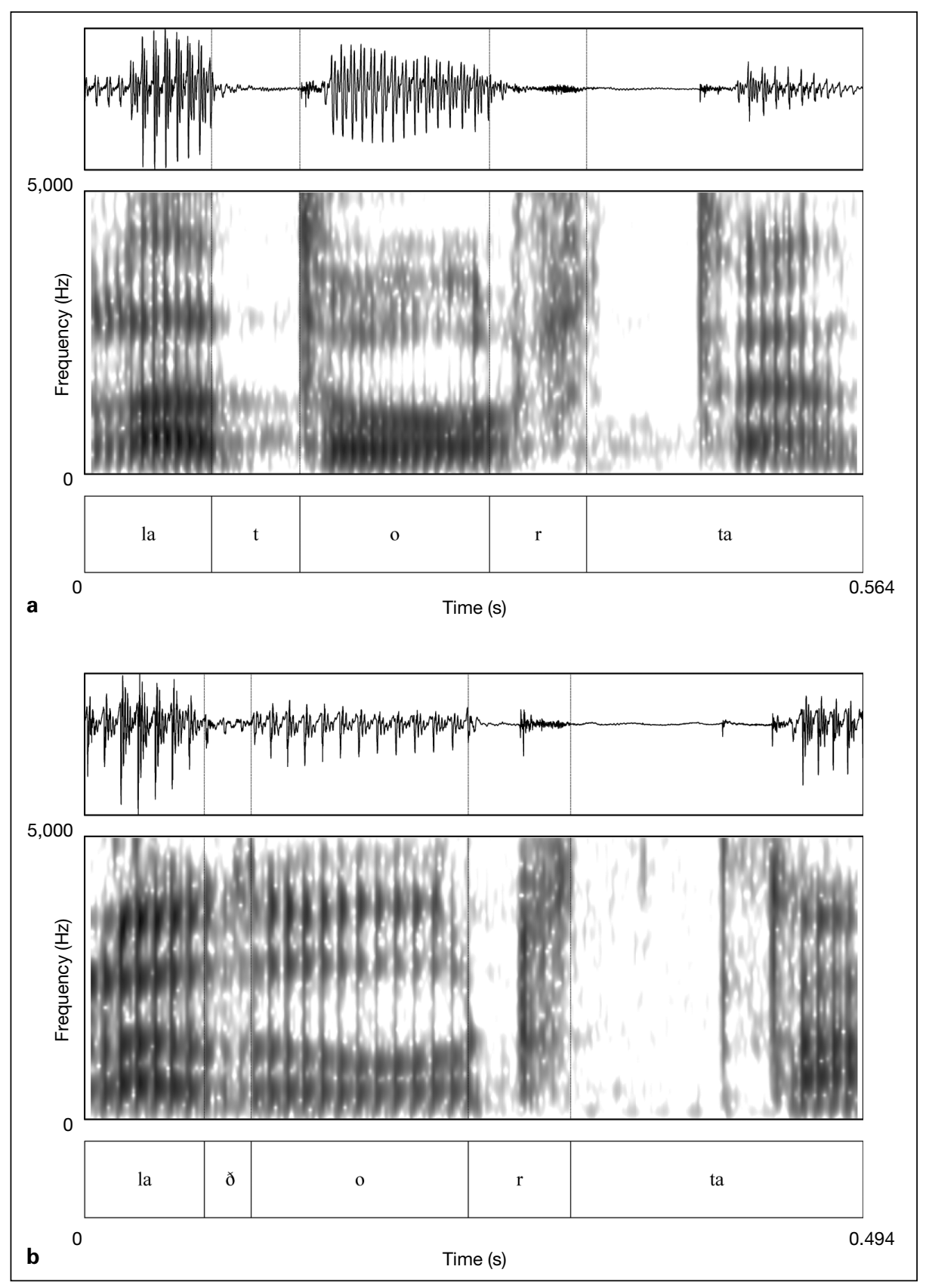

Fig. 9. Two realizations of la torta 'the cake', where the word-initial/t/ has been realized as a voiceless stop (a) and as a voiced approximant (b). 


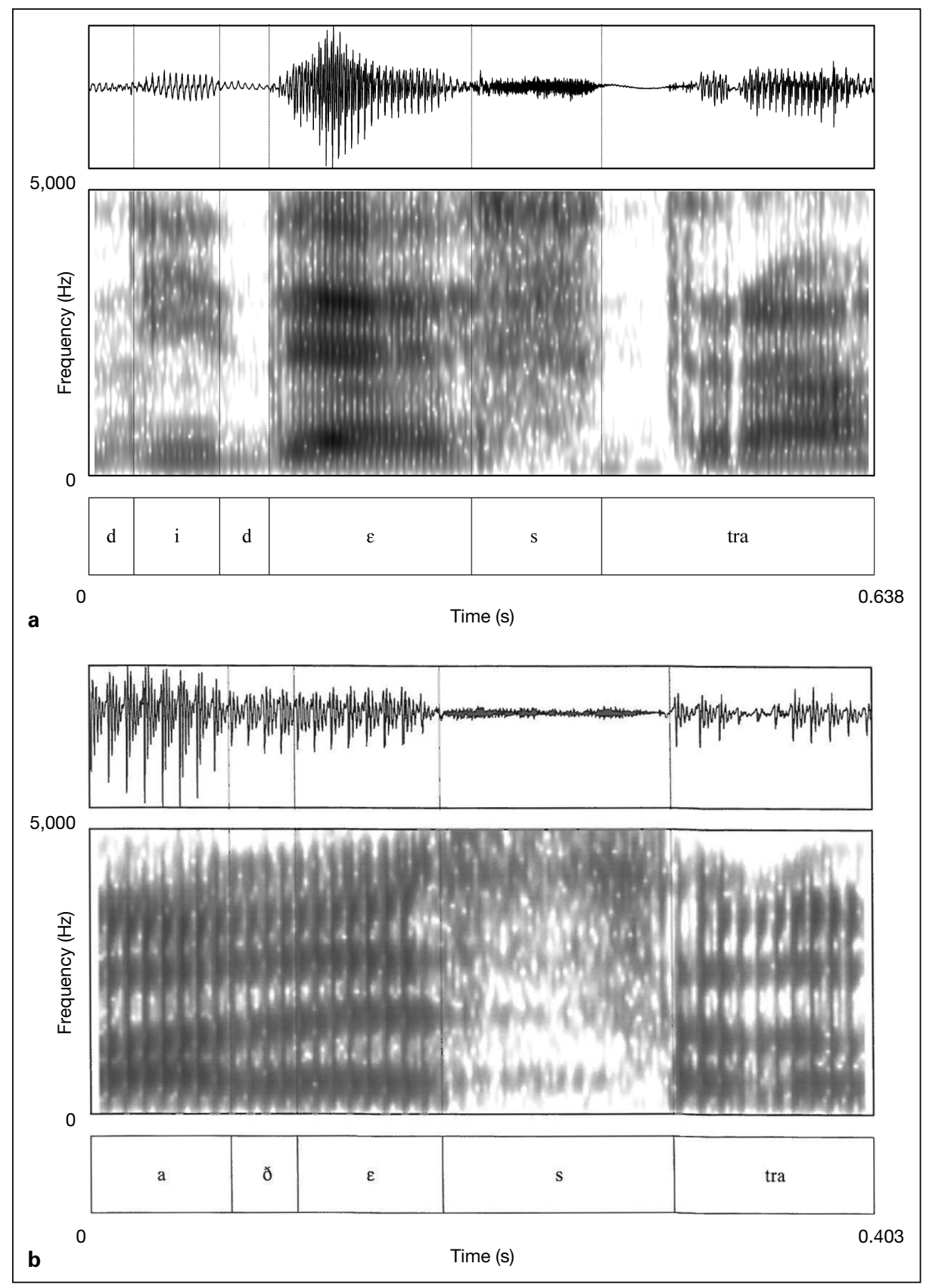

Fig. 10. Two realizations of $/ d /$ in the word destra 'right hand'. In a, di destra 'of the right', /d/ has a constricted realization, as a voiced stop. In $\mathbf{b}$, (l)a destra 'the right hand', the same consonant has been realized as a weak approximant. 
contributes to maintaining the contrast with $/ \mathrm{p} /$. For the pairs $/ \mathrm{t} /-/ \mathrm{d} /$ and $/ \mathrm{k} /-/ \mathrm{g} /$ there is greater overlap than in Spanish. This is due not only to the allophony of the voiceless plosives, but also to that of their voiced counterparts. In Spanish, /b d g/ are systematically realized as approximants in the intervocalic position. When $/ \mathrm{p} \mathrm{t} \mathrm{k} /$ are voiced, they are also most frequently realized without full occlusion, but with a somewhat greater degree of constriction and greater duration than $/ \mathrm{b} \mathrm{d} \mathrm{g/.} \mathrm{In} \mathrm{our} \mathrm{Rome} \mathrm{Italian} \mathrm{corpus,} \mathrm{on}$ the other hand, the weakening of $/ \mathrm{d} g /$ is only optional. These segments are variably realized with complete or incomplete occlusion. The result appears to be considerable convergence between $/ \mathrm{t} \mathrm{k} /$ and $/ \mathrm{d} \mathrm{g} /$.

As mentioned, in both languages $/ \mathrm{k} /$ is more frequently voiced than the other two voiceless plosives. Another point of agreement between both languages is that voicing of postvocalic $/ \mathrm{p} \mathrm{t} \mathrm{k/} \mathrm{takes} \mathrm{place} \mathrm{both} \mathrm{word-internally} \mathrm{and} \mathrm{word-initially.} \mathrm{In} \mathrm{Hualde} \mathrm{et}$ al. [2011] no significant difference was found between these two contexts. In our Rome Italian corpus, $/ \mathrm{p} /$ and $/ \mathrm{t} /$ (but not $/ \mathrm{k} /$ ) are more frequently voiced word-internally than word-initially.

Hualde et al. [2011] notice that the voicing of intervocalic $/ \mathrm{p} \mathrm{t} \mathrm{k} /$ is style-dependent in Iberian Spanish, since the phenomenon is only sporadic in a corpus of read speech (less than $4 \%$ of tokens) by the same 20 speakers who produced their conversational corpus. It remains to be determined to what extent $/ \mathrm{p} \mathrm{t} \mathrm{k/} \mathrm{are} \mathrm{voiced} \mathrm{and} \mathrm{weakened} \mathrm{in}$ more formal styles in Rome Italian.

We would like to end this paper with some speculation regarding sound change. The question that arises is how or whether the type of contrast with substantial phonetic overlap between phonemic categories that our analysis has revealed can be stable. What prevents the phonological contrast between voiced and voiceless stops from being lost? It seems that the answer has to be somewhat different for word-internal and for word-initial contexts.

In the case of word-internal intervocalic coronal and velar plosives, it may be the knowledge about specific items as permitting or not a pronunciation with a voiceless realization of the segment that supports the contrast; that is, knowing that, for instance, in dato 'given' the medial consonant can be produced as either voiceless or voiced, whereas the medial consonant in dado 'dice' only admits voiced realizations. This is not very different from the preservation of the phonological contrast under flapping in American English, e.g. petal vs. pedal [Cravens, 2002]. Clearly, knowledge of the standard spelling of words may play a role, as D'Achille [2004] suggests.

Although the situation in Rome Italian, with what appears to be substantial overlap between phonemes, has not led to massive phonemic recategorization, the diachronic voicing of word-medial intervocalic stops that we find in Western Romance languages (e.g. LATU > Sp. lado 'side') probably went through the stage that we are now witnessing in Rome Italian [Weinrich, 1958].

Following Cravens [2002], we suggest that, for instance, in Western Romance /lato/ 'side' was realized at some point as [lato] [lado] [laðo], as we find in presentday Rome Italian. Later, this lexical item became /lado/ when a pronunciation [lato] was no longer possible for this word (i.e. no longer a socially recognized pronunciation of this lexical item). Notice that for sound change (= phonemic recategorization) to take place no mistake on the part of the listener [Ohala, 1974, 2003] needs to be assumed. Only lack of knowledge or a failure of memory is required. A speaker may recategorize, say, [bicða] as /bicda/ if s/he does not know or does not remember 
that this word can also be pronounced [bicta]. No misinterpretation of speaker's phonological intention is necessary for this to happen.

Very likely something that contributed to the whole-sale recategorization of intervocalic voiceless plosives as voiced in Western Romance was the concurring shortening of geminates, so that a new opposition (e.g. /-tt-/ >/-t-/, /-t-/ >/-d-/) was established. In present-day Rome Italian, on the other hand, geminate $/ \mathrm{pp} t \mathrm{tt} /$ are reliably different

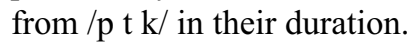

Word-initially, the evidence for the underlying nature of the segment is more abundant, since it is revealed when the word is utterance-initial or follows a consonant, as well as in contexts of RS. This knowledge could prevent recategorization (sound change) in word-initial position, as was prevented in Western Romance, e.g. Lat. ILLA PORTA > Sp. la /p/uerta 'the door' (not *la /b/uerta) [Weinrich, 1958; Hall, 1964; Cravens, 2002].

As a synchronic process of reduction, voicing is affecting both word-initial and word-medial intervocalic consonants, but, for the reasons just given, recategorization leading to sound change is much more likely in word-internal position. The synchronic facts of Rome Italian offer support for the hypothesis that lenition starts as an across-the-board process, e.g. /aka/ $\rightarrow$ [aka] [aga] and that the restriction to the word-internal process that we find, for instance, in the very similar process of Western Romance lenition, results from subsequent recategorization only in the word-internal context, e.g. /aka/ $\rightarrow$ [aka] [aga] $>$ /aga/ $\rightarrow$ [aga], where the environment does not change across utterances [Weinrich, 1958; etc., also Hualde et al., 2011].

To summarize, our acoustic analysis has shown that in Rome Italian phonemic voiceless stops undergo a great degree of lenition in intervocalic position, confirming prior description. Lenited tokens of phonemic $/ \mathrm{p} \mathrm{t} \mathrm{k/} \mathrm{can} \mathrm{be} \mathrm{very} \mathrm{short} \mathrm{and} \mathrm{have} \mathrm{a}$ very weak constriction with uninterrupted voicing. This raises the question of how or whether the contrast with phonemic $/ \mathrm{b} \mathrm{d} \mathrm{g} /$ is maintained. Our analysis has shown that in the case of the velars and the coronals, the two phonemic series show considerable overlap. The situation is one where the phonologically voiceless series has a range of allophonic realizations that includes those of the voiced phonemes. For the labials, the gemination of $/ \mathrm{b} /$ prevents neutralization.

\section{Acknowledgments}

We are grateful to Michele Loporcaro, three anonymous reviewers for this journal, and the Associate Editor Daniel Recasens for very helpful comments. We would also like to thank Miquel Simonet and Francisco Torreira for help with the PRAAT scripts. 


\section{Appendix}

\section{Token Counts by Context}

Table 1. Distribution of allophones of $/ \mathrm{p} \mathrm{t} \mathrm{k} /$ by following context

\begin{tabular}{lllll}
\hline \multirow{2}{*}{ Consonant } & Following segment & Allophone & & \\
\cline { 3 - 4 } & & voiceless stop & voiced stop/approximant & other \\
\hline liquid & $51(38.9 \%)$ & $79(60.3 \%)$ & $1(0.8 \%)$ \\
& glide & $22(46.8 \%)$ & $24(51.1 \%)$ & $1(2.1 \%)$ \\
/i/ & $6(30 \%)$ & $14(70 \%)$ & 0 \\
/e, e/ & $23(39 \%)$ & $36(61 \%)$ & 0 \\
/u/ & $16(45.7 \%)$ & $19(54.3 \%)$ & 0 \\
/o, o/ & $24(45.3 \%)$ & $29(54.7 \%)$ & 0 \\
/a/ & $56(53.3 \%)$ & $49(46.7 \%)$ & 0 \\
liquid & $33(63.5 \%)$ & $19(36.5 \%)$ & 0 \\
glide & $1(20 \%)$ & $4(80 \%)$ & 0 \\
/i/ & $11(35.5 \%)$ & $19(61.3 \%)$ & $1(3.2 \%)$ \\
/e,, / & $18(58.1 \%)$ & $12(38.7 \%)$ & $2(10.5 \%)$ \\
/u/ & $5(26.3 \%)$ & $12(63.2 \%)$ & $1(1.5 \%)$ \\
/o, o/ & $27(40.9 \%)$ & $38(57.6 \%)$ & $2(4.5 \%)$ \\
/a/ & $25(56.8 \%)$ & $17(38.6 \%)$ & 0 \\
liquid & $1(9.1 \%)$ & $10(90.9 \%)$ & $7(5.2 \%)$ \\
glide & $49(36.6 \%)$ & $78(58.2 \%)$ & 0 \\
/i/ & $2(50 \%)$ & $2(50 \%)$ & $3(4.1 \%)$ \\
/e, e/ & $11(14.9 \%)$ & $60(81.1 \%)$ & 0 \\
/u/ & $18(41.9 \%)$ & $25(58.1 \%)$ & $1(1 \%)$ \\
/o, o/ & $35(36.1 \%)$ & $61(62.9 \%)$ & $6(12.2 \%)$ \\
/a/ & $11(22.4 \%)$ & $32(65.3 \%)$ &
\end{tabular}

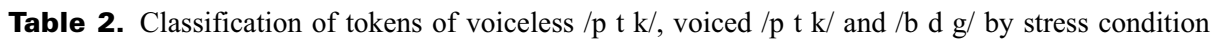
separated by place

\begin{tabular}{|c|c|c|c|}
\hline \multirow[t]{2}{*}{ Consonant } & \multicolumn{3}{|c|}{ Following vowel } \\
\hline & stressed & unstressed & total \\
\hline Voiceless /p/ & $106(53.5 \%)$ & $92(46.5 \%)$ & 198 \\
\hline Voiced /p/ & $116(46.4 \%)$ & $134(53.6 \%)$ & 250 \\
\hline$/ \mathrm{b} /$ & $40(69 \%)$ & $18(31 \%)$ & 58 \\
\hline Voiceless /t/ & $58(48.3 \%)$ & $62(51.7 \%)$ & 120 \\
\hline Voiced /t/ & $37(30.6 \%)$ & $84(69.4 \%)$ & 121 \\
\hline$/ \mathrm{d} /$ & $172(37.3 \%)$ & $289(62.7 \%)$ & 461 \\
\hline Voiceless /k/ & $87(68.5 \%) f$ & $40(31.5 \%)$ & 127 \\
\hline Voiced /k/ & $146(54.5 \%)$ & $122(45.5 \%)$ & 268 \\
\hline \multirow[t]{2}{*}{$/ g /$} & $46(69.7 \%)$ & $20(30.3 \%)$ & 66 \\
\hline & 808 & 861 & 1,669 \\
\hline
\end{tabular}




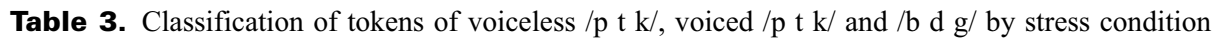
without separating by place

\begin{tabular}{lllr}
\hline Consonant & \multicolumn{2}{l}{ Following vowel } & \\
\cline { 2 - 4 } & stressed & unstressed & total \\
\hline Voiceless /p, t, k/ & $251(56.4 \%)$ & $194(43.6 \%)$ & 445 \\
Voiced /p, t, k/ & $299(46.8 \%)$ & $340(53.2 \%)$ & 639 \\
/b, d, g/ & $258(44.1 \%)$ & $327(55.9 \%)$ & 585 \\
& 808 & 861 & 1,669 \\
\hline
\end{tabular}

Table 4. Classification of tokens of voiceless $/ \mathrm{p} \mathrm{t} \mathrm{k/,} \mathrm{voiced} / \mathrm{p} \mathrm{t} \mathrm{k/} \mathrm{and} \mathrm{/b} \mathrm{d} \mathrm{g/,} \mathrm{separated} \mathrm{by} \mathrm{place,}$ according to the height of the following nuclear vowel

\begin{tabular}{lcrrr}
\hline Consonant & \multicolumn{2}{l}{ Following vowel } & & mid \\
\cline { 2 - 5 } & high & \multicolumn{1}{l}{ low } & $60(30.3 \%)$ & total \\
\hline Voiceless /p/ & $40(20.2 \%)$ & $98(49.5 \%)$ & $88(35.2 \%)$ & 198 \\
Voiced /p/ & $50(20 \%)$ & $112(44.8 \%)$ & $16(27.6 \%)$ & 250 \\
/b/ & $9(15.5 \%)$ & $33(56.9 \%)$ & $77(64.2 \%)$ & 58 \\
Voiceless /t/ & $16(13.3 \%)$ & $27(22.5 \%)$ & $68(56.2 \%)$ & 120 \\
Voiced /t/ & $35(28.9 \%)$ & $18(14.9 \%)$ & $252(54.7 \%)$ & 121 \\
/d/ & $147(31.9 \%)$ & $62(13.4 \%)$ & $63(49.6 \%)$ & 461 \\
Voiceless /k/ & $32(25.2 \%)$ & $32(25.2 \%)$ & $192(71.6 \%)$ & 127 \\
Voiced /k/ & $32(11.9 \%)$ & $44(16.4 \%)$ & $15(22.7 \%)$ & 66 \\
/g/ & $14(21.2 \%)$ & $37(56.1 \%)$ & 831 & 66 \\
& 375 & 463 & & \\
\hline
\end{tabular}

\section{References}

Absalom, M.; Stevens, M.; Hajek, J.: A typology of spreading, insertion and deletion or what you weren't told about raddoppiamento sintattico in Italian; in Proc. 2002 Conf. of the Aust. Ling. Soc. Available at: Univ. Melbourne Library digital repository.

Albano Leoni, F.; Maturi, P.: Le occlusive sorde nell' italiano di Nusco; in Gianelli, Maraschio, Poggi Salani, Vedovelli, Tra rinascimento e strutture attuali. Saggi di linguistica italiana, pp. 253-258 (Rosenberg \& Sellier, Torino 1991).

Baayen, H.: Analyzing Linguistic Data: A practical introduction to statistics using R (CUP, Cambridge 2008).

Bernhard, G.: Das Romanesco des ausgehenden 20. Jahrhunderts: Variationslinguistische Untersuchungen. Beihefte zur Zeitschrift für romanische Philologie, 291 (Niemeyer, Tübingen 1998).

Bertinetto, P.P.; Loporcaro, M.: The sound pattern of Standard Italian, as compared with the varieties spoken in Florence, Milan and Rome. J. Int. Phonet. Assoc. 35: 131-151 (2005).

Boersma, P.: Praat, a system for doing phonetics by computer. Glot int. 5: 341-345 (2001).

Borrelli, D.: Raddoppiamento sintattico in Italian: A synchronic and diachronic cross-dialectal study (Routledge, London 2002).

Canalis, S.: Phonetic and phonological aspects of intervocalic stop voicing in Old Tuscan. LSRL 40, Seattle, March 2010.

Cole, J.; Hualde, J.I.; Iskarous, K.: Effects of prosodic context on /g/ lenition in Spanish; in Fujimura, Palek, Proc. $4^{\text {th }}$ Int. Ling. Phonet. Conf., pp. 575-589 (Karolinium Press, Prague 1999).

Cravens, T.: Intervocalic consonant weakening in a phonetic-based phonology: Foleyan hierarchies and the Gorgia Toscana. Theoret. Ling. 11: 269-310 (1984).

Cravens, T.: Comparative historical dialectology: Italo-Romance clues to Ibero-Romance sound change (Benjamins, Amsterdam 2002).

$\overline{240} \quad \overline{\text { Phonetica 2011;68:215-242 }} \quad \overline{\text { Hualde/Nadeu }}$


D'Achille, P.: Aspetti variazionalli nell'italiano parlato a Roma; in Bombi, Fusco, Città plurilingue: Lingue e culture a confronto in situazioni urbane/Multilingual cities: Perspectives and insights on languages and cultures in urban areas, pp. 176-189 (Centro Internazionale sul plurilinguismo, Udine 2004).

D'Achille, P.; Stefinlongo, A.: La lenizione delle sorde a Roma tra diacronia e sincronia; in Marcato, L'Italia dei dialetti. Atti del Convegno. Sappada/Plodn (Belluno), 28 giugno-2 luglio 2007, pp. 183-196 (Unipress, Padova 2008).

Giannelli, L.; Cravens, T.: Consonantal weakening; in Maiden, Parry, The dialects of Italy, pp. 32-40 (Routledge, London 1997).

Giannelli, L.; Savoia, L.M.: L'indebolimento consonantico in Toscana, I. Rivista Italiana di Dialettologia 2: 25-58 (1978).

Giannelli, L.; Savoia, L.M.: L'indebolimento consonantico in Toscana, II. Rivista Italiana di Dialettologia 3-4: 39-101 (1979-1980).

Hall, R.A. Jr.: Initial consonants and syntactic doubling in West Romance. Language 40: 551-556 (1964).

Hualde, J.I.: Quasi-phonemic constrasts in Spanish; in Chand, Kelleher, Rodríguez, Schmeiser, Proc. 23rd West Coast Conf. on Formal Ling., pp. 374-398 (Cascadilla Press, Somerville 2004).

Hualde, J.I.; Nadeu, M.; Simonet, M.: Lenition and phonemic contrast in two Catalan dialects; in Colina, Olarrea, Carvalho, Romance Linguistics 2009: Selected Papers from the 39 ${ }^{\text {th }}$ Linguistic Symposium on Romance Languages, pp. 63-79 (Benjamins, Amsterdam 2010).

Hualde, J.I.; Simonet, M.; Nadeu, M.: Consonant lenition and phonological recategorization. Lab. Phonol. 2: 301329 (2011).

Kingston, J.: Lenition; in Colantoni, Steele, Selected Proc. $3^{\text {rd }}$ Conf. on Laboratory Approaches to Spanish Phonology, pp. 1-31 (Cascadilla Proceedings Project, Somerville 2008).

Kirchner, R.: Geminate inalterability and lenition. Language 76: 509-545 (2000).

Labov, W.: Principles of Linguistic Change. Vol. 1: Internal factors (Blackwell, Oxford 1994).

Ladd, R.D.; Scobbie, J.: External sandhi as gesture overlap? Counter-evidence from Sardinian; in Local, Ogden, Temple, Phonetic interpretation: Papers in Laboratory Phonology VI, pp. 164-182 (Cambridge, CUP 2003).

Lavoie, L.: Consonant strength: Phonological patterns and phonetic manifestations (Garland, New York 2001).

Lehiste, I.: Suprasegmentals (Cambridge, MIT Press 1970).

Lehiste, I.; Peterson, G.E.: Vowel amplitude and phonemic stress in American English. J. acoust. Soc. America 31 : 428-435 (1959).

Lewis, A.M.: Weakening of intervocalic /ptk/ in two Spanish dialects: Toward the quantification of lenition processes; Ph.D. diss. University of Illinois at Urbana-Champaign (2001).

Loporcaro, M.: L'origine del raddoppiamento fonosintattico. Saggio di fonologia diacronica romanza (Basel, Francke 1997)

Loporcaro, M.: Profilo linguistico dei dialetti italiani (Laterza, Bari 2009).

Machuca Ayuso, M.: Las obstruyentes no continuas del español: Relación entre las categorías fonéticas y fonológicas en habla espontánea; Ph.D. diss. Universitat Autònoma de Barcelona (1997).

Marotta, G.: Non solo spiranti: La 'gorgia toscana' nel parlato di Pisa. L'Italia dialettale 62: 26-60 (2001).

Marotta, G.: Il consonantismo romano. Processi fonologici e aspetti acustici; in Albano Leoni, Giordano, Italiano parlato. Analisi di un dialogo, pp. 1-24 (Liguori, Napoli 2005).

Marotta, G.: Lenition in Tuscan Italian (Gorgia Tuscana); in Brandão de Carvalho, Scheer, Ségéral, Lenition and fortition, pp. 235-272 (Mouton de Gruyter, Berlin 2008).

Marotta, G.; Sorianello, P.: Lenizione e sonorizzazione nell'italiano cosentino: Un'analisi sperimentale. L'Italia dialettale 55: 65-122 (1992).

Martínez Celdrán, E.: Sonorización de las oclusivas sordas en una hablante murciana: Problemas que plantea Estudios Fonética exp. 18: 253-271 (2009).

Martínez-Celdrán, E.; Regueira, X.I.: Spirant approximants in Galician. J. Int. Phonet. Assoc. 38: 51-68 (2008).

Nocchi, N.; Schmid, S.: Lenition of voiceless fricatives in two varieties of southern Italian. Proc. $16^{\text {th }}$ ICPhS, Saarbrücken 2007, pp. 1497-1500.

Oftedal, M.: Lenition in Celtic and in Insular Spanish: The second voicing of stops in Gran Canaria (Universitetsforlaget, Oslo 1985).

Ohala, J.: Experimental historical phonology; in Anderson, Jones, Historical linguistics, vol. 2, pp. 353-389 (North Holland, Amsterdam 1974).

Ohala, J.: Phonetics and historical phonology; in Joseph, Janda, The handbook of historical linguistics, pp. 669-686 (Blackwell, Malden 2003).

Ortega-Llebaria, M.: Interplay between phonetic and inventory constraints in the degree of spirantization of voiced stops: Comparing intervocalic /b/ and intervocalic /g/ in Spanish and English; in Face, Laboratory approaches to Spanish Phonology, pp. 237-253 (Mouton de Gruyter, Berlin 2004).

Parrell, B.: Articulation from acoustics: Estimating constriction degree from the acoustic signal. J. acoust. Soc. Am. 128: 2289 (2010).

Payne, E.: Phonetic variation in Italian consonant gemination. J. Int. Phonet. Assoc. 35: 153-181 (2005).

Pickett, E.R.; Blumstein, S.E.; Burton, M.W.: Effects of speaking rate on the singleton/geminate consonant contrast in Italian. Phonetica 56: 135-157 (1999).

Port, R.; Crawford, P.: Incomplete neutralization and pragmatics in German. J. Phonet. 17: 257-282 (1989).

Port, R.; O’Dell, M.: Neutralization of syllable-final voicing in German. J. Phonet. 13: 455-471 (1985) 
Recasens, D.: Weakening and strengthening in Romance revisited. Riv. Ling. 14: 327-373 (2002).

Rohlfs, G.: Grammatica storica della lingua italiana e dei suoi dialetti (Torino, Einaudi 1966-1969).

Scobbie, J.; Stuart-Smith, J.: Quasi-phonemic contrast and the fuzzy inventory: Examples from Scottish English; in Avery, Dresher, Rice, Contrast: Perception and acquisition. Selected papers from the $2^{\text {nd }}$ Int. Conf. on Contrast in Phonology, pp. 87-113 (Mouton, Berlin 2008).

Soler, A.; Romero, J.: The role of duration in stop lenition in Spanish. Proc. 14 $4^{\text {th }}$ ICPhS, San Francisco 1999, pp. 483-486.

Sorianello, P.: Un'analisi acustica della 'gorgia' fiorentina. Italia dialettale 62: 61-94 (2001).

Stefinlongo, A.: Note sulla situazione sociolinguistica romana: Preliminari per una recerca. Riv. Ital. Dialettologia 9: 43-67 (1985).

Stevens, M.; Hajek, J.: Raddoppiamento sintattico and word-medial gemination in Italian: Are they the same or are they different? The evidence from spontaneous speech; in Gess, Rubin, Theoretical and experimental approaches to Romance Linguistics, pp. 257-271 (Benjamins, Amsterdam 2005).

Torreblanca, M.: La sonorización de las oclusivas sordas en el habla toledana. Bol. Real Acad. Española 56: 117165 (1976).

Villafaña Dalcher, C.: Consonant weakening in Florentine Italian: An acoustic study of gradient and variable sound change; Ph.D. diss. Georgetown University (2006)

Weinrich, H.: Phonologische Studien zur romanischen Sprachgeschichte (Aschendorff, Münster 1958). 